\title{
27. DANIAN CALCAREOUS NANNOFOSSIL SUCCESSION AT SITE 738 IN THE SOUTHERN INDIAN OCEAN ${ }^{1}$
}

\author{
Wuchang Wei $^{2}$ and James J. Pospichal ${ }^{2}$
}

\begin{abstract}
An apparently complete Danian section was recovered at ODP Site 738 on the southern Kerguelen Plateau. Calcareous nannofossils are abundant and moderately preserved in the section. A number of taxa common in middle or low latitudes, such as Braarudosphaera, Biscutum? romeinii, Biscutum? parvulum, Cyclagelosphaera, Octolithus multiplus, and Toweius petalosus are absent at Site 738. On the other hand, a bloom of Hornibrookina occurs at Site 738 only slightly $(15 \mathrm{~cm})$ above the Cretaceous/Tertiary boundary as defined by the iridium peak. Species of Chiasmolithus and Prinsius are very abundant. This gives the nannofossil assemblages distinct high-latitude characteristics and suggests significant latitudinal thermal gradients in the Danian oceans. A Danian nannofossil zonation for the Antarctic region is proposed, which utilizes traditional markers and several nontraditional markers, i.e., the first occurrences of Hornibrookina, Prinsius martinii, and Chiasmolithus bidens, and the last occurrence of Hornibrookina teuriensis. Quantitative analyses of the calcareous nannofossil assemblages from Site 738 reveal four steps of rapid floral changes in the early Danian before relatively stable nannofloral conditions were reached at about $63.8 \mathrm{Ma}$.
\end{abstract}

\section{INTRODUCTION}

Large amounts of data have rapidly accumulated during the last several years on mass extinctions across the Cretaceous/Tertiary boundary. However, quantitative paleontological data for the entire Danian are still scarce, and examination of the repopulation processes of plankton and benthos in the early Paleocene oceans has yet to be carried out in different oceans, environments (shelf vs. oceanic), and latitudes. Many questions need to be addressed, for example, are high-latitude assemblages different from those in the middle or low latitudes immediately after the Cretaceous/Tertiary boundary and how do the latitudinal differentiations of assemblages change through time? What are the rates of diversification and how do they vary from one biogeographic region to another? Is there an "equilibrium" diversity beyond which diversification cannot progress? Is this equilibrium diversity reached synchronously?

Ocean Drilling Program (ODP) Leg 119 recovered an apparently continuous Cretaceous-Tertiary transition and a biostratigraphically complete Danian section at Site 738 on the southern Kerguelen Plateau, the highest latitude Danian sequence ever recovered in the Indian Ocean (Fig. 1). As complete calcareous Danian sections recovered from southern high latitudes are rare, with the only counterpart being that recovered at Site 690 (Leg 113) on Maud Rise in the Weddell Sea (Pospichal and Wise, 1990 ), the Danian section at Site 738 is especially valuable, serving as a southern anchor in the Indian Ocean for paleobiogeographic and paleoecological studies, and providing crucial information on the evolution of oceanic biota at high latitudes.

The first objective of this study is to provide calcareous nannofossil biostratigraphic information for the Danian section from Site 738. The second objective is to examine quantitatively calcareous nannofossil species abundance patterns in order to investigate the nature of calcareous nannoplankton evolution and diversification during the first several million years following the Cretaceous/Tertiary boundary extinction event. This should

\footnotetext{
${ }^{1}$ Barron, J., Larsen, B., et al., 1991. Proc. ODP, Sci. Results, 119: College Station, TX (Ocean Drilling Program).

2 Department of Geology, Florida State University, Tallahassee, FL 32306,
}

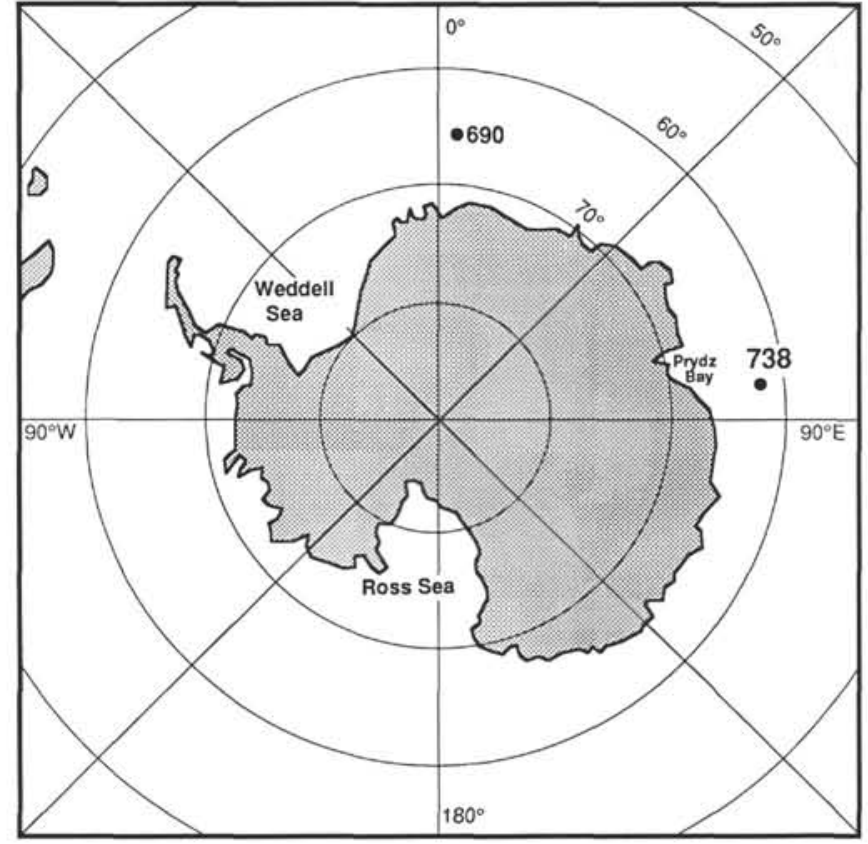

Figure 1. Location map of Site 738 and a comparison site, Site 690 (Leg 113).

shed some light on the paleoenvironment of the southern high latitudes in the early Paleocene. The calcareous nannofossil succession established here will serve as an important reference in the Southern Ocean. This study is the first to quantitatively analyze calcareous nannofossil assemblages of the entire Danian. For additional information on the Cretaceous/Tertiary boundary and the Paleocene calcareous nannofossils at Site 738 see Thierstein et al. (this volume) and Wei and Thierstein (this volume).

Pioneering work on calcareous nannofossils across the Cretaceous/Tertiary boundary interval was carried out by Bramlette and Martini (1964). Subsequently, a number of nannofossil biostratigraphic studies of the Cretaceous/Tertiary boundary and 
the early Paleocene have been completed, e.g., Edwards (1966) in New Zealand, Hay and Mohler (1967) in France, Perch-Nielsen (1969) in Denmark, Worsley (1974) in Alabama, Percival and Fisher (1977) in northern Spain, Romein $(1977,1979)$ in southern Spain, Thierstein and Okada (1979) in the North Atlantic, Perch-Nielsen (1981a) in Tunisia, Percival (1984) in the South Atlantic, Monechi (1985) in the North Pacific, Jiang and Gartner (1986) in Texas, Heck and Prins (1987) in the North Sea, and Varol (1989) in Turkey. Reports of southern high-latitude Cretaceous/Tertiary boundary and Danian nannofossils include Edwards (1973), and Pospichal and Wise (1990). Comprehensive reviews of calcareous nannofossil stratigraphy and assemblages across Cretaceous/Tertiary boundaries in various parts of the world were presented by Thierstein (1981), Perch-Nielsen et al. (1982), and Smit and Romein (1985). Haq and Lohmann (1976) and Haq et al. $(1977,1979)$ carried out quantitative biogeographic studies of calcareous nannofossils for selected time slices of the Danian. They reported that there was a latitudinal differentiation of nannofossil assemblages and that there were major latitudinal migrations of these assemblages as a response to major changes in climate.

\section{MATERIAL AND METHODS}

ODP Site 738 is located at $62^{\circ} 42.543^{\prime} \mathrm{S}, 82^{\circ} 47.245^{\prime} \mathrm{E}$, in $2252 \mathrm{~m}$ of water. The site lies on the southern part of the Kerguelen Plateau, north of the modern Antarctic Divergence and near the southern limit of influence of the Antarctic Circumpolar Current. Site 738 was probably near sea level at $90 \mathrm{Ma}$ based on the shallow marine and volcaniclastic rocks recovered from the basement, and represented an outer shelf environment (400$600 \mathrm{~m}$ ) in the late Maestrichtian according to benthic foraminifers (Barron, Larsen, et al., 1989). During the Danian, Site 738 was probably in about $1000 \mathrm{~m}$ of water assuming a uniform rate of subsidence.

The Danian section at Site 738 consists of white to greenishgray calcareous chalk with chert nodules and fragments. The chalk is partially silicified. Major components of the sediment include micrite, calcareous nannofossils, foraminifers, and clay. The bottom of the Danian (Section 119-738C-20R-5, $96 \mathrm{~cm}$, to $-20 \mathrm{R}-5,83 \mathrm{~cm}$ ) is laminated claystone, with distinct laminae on a millimeter scale. An iridium peak occurs at the base of this laminated section (Schmitz, this volume). For detailed description of the section, we refer the readers to Barron, Larsen, et al. (1989).

Samples used in this study were taken from Cores 119-738C$17 \mathrm{R}$ to $-20 \mathrm{R}$ at about $50-\mathrm{cm}$ intervals, which represent an average sampling frequency of about 0.05 m.y.. Smear slides were made directly from the unprocessed samples to avoid losing smaller-sized specimens. Scanning electron microscope (SEM) stubs were also made directly from the unprocessed samples. The SEM was used to identify the small nannofossil species in about a dozen samples, mostly from the lower Danian.

The relative abundances of the calcareous nannofossil species were first estimated with a light microscope at a magnification of about $\times 1600$ and recorded as follows: $\mathrm{V}=$ very abundant, more than 10 specimens per field of view; $\mathrm{A}=$ abundant, $1-10$ specimens per field of view; $C=$ common, 1 specimen per 2-10 fields of view; $F=$ few, 1 specimen per 11-50 fields of view; $\mathrm{R}=$ rare, 1 specimen per $51-300$ fields of view; $\mathrm{N}=$ not found in 300 fields of view. These semiquantitative data are used to construct the range chart from which nannofossil biostratigraphy is established. Preservation of assemblages is indicated by $\mathrm{G}=$ good, little overgrowth and/or etching; $\mathbf{M}=$ moderate, overgrowth and/or etching are apparent, but identification at species level is generally not impaired; $\mathrm{P}=$ poor, significant overgrowth and/or etching, identification of some species is impaired.
Calcareous nannofossil species recorded in this study are listed in Table 1, and most of these species are documented with SEM and light micrographs in Plates 1 through 4 of this paper. Bibliographic references for these species can be found in Loeblich and Tappan (1966, 1968, 1969, 1970a, 1970b, 1971, 1973), van Heck (1979a, 1979b, 1980a, 1980b, 1981a, 1981b, 1982a, 1982b, 1983), or Steinmetz (1985a, 1985b, 1986, 1987a, 1987b, 1988a, 1988b, 1989).

For the quantitative study of the nannofossil assemblages, about 300 specimens of calcareous nannofossils were counted along random traverses of each slide. Rare species generally are not encountered in these first 300 counts. This does not hinder the usefulness and interpretation of the data, because our primary goal here is to examine major components in the samples, which significantly affect the population dynamics. Paleoenvironmental information is extracted from these major components. Species less than a few percent or abundance change less than a few percent are not considered statistically significant in this study.

In order to make it practical to count the species for large numbers of samples and to obtain consistent results, it was necessary to group some taxa. We counted Chiasmolithus bidens and Chiasmolithus danicus as a group during the collection of the quantitative data. These two species differ by the presence of axial lines in the cross bars of the former species and the two

Table 1. Calcareous nannofossils considered in this paper. In alphabetical order of generic epithets; plate and figure numbers refer to illustrations in this paper.

Ahmuellerella octoradiata (Gorka) Bukry, 1969

Arkhangelskiella cymbiformis Veskshina, 1959

Biscutum constans (Gorka) Black, 1967. Pl. 1, Fig. 9; Pl. 2, Fig. 2

Biscutum? parvulum Romein, 1979

Biscutum? romeinii Perch-Nielsen, 1981

Chiasmolithus bidens (Bramlette and Sullivan) Hay and Mohler, 1967. PI. 4, Figs, 5,6

Chiasmolithus danicus (Brotzen) Hay and Mohler, 1967. Pl. 4, Figs. 3, 4, 7

Coccolithus pelagicus (Wallich) Schiller, 1930. PI. 4, Fig. 8

Coccolithus subpertusus (Hay and Mohler) Wei and Pospichal, n. comb.

Cretarhabdus conicus Bramlette and Martini, 1964

Cretarhabdus surirellus (Deflandre) Reinhardt, 1970

Cribrosphaerella daniae Perch-Nielsen, 1977

Cribrosphaerella ehrenbergii (Arkhangelsky) Deflandre, 1952. Pl. 4, Fig. 10

Cruciplacolithus edwardsii Romein, 1979. PI. 3, Figs. 4, 7

Cruciplacolithus primus Perch-Nielsen, 1977

Cruciplacolithus tenuis (Stradner) Hay and Mohler in Hay et al., 1967

Cyclagelosphaera reinhardtii (Perch-Nielsen) Romein, 1977

Eiffellithus turriseiffelii (Deflandre) Reinhardt, 1965

Fasciculithus tympaniformis Hay and Mohler in Hay et al., 1967

Fasciculithus ulii Perch-Nielsen, 1971

Gartnerago obliquium (Stradner) Noël, 1970

Hornibrookina teuriensis Edwards, 1973. Pl. 2, Figs. 5-7

Kamptnerius magnificus Deflandre, 1959

Lithraphidites carniolensis Deflandre, 1963

Lucianorhabdus cayeuxii Deflandre, 1959

Markalius apertus Perch-Nielsen, 1979. PI. 1, Fig. 11

Markalius inversus (Deflandre) Bramlette and Martini, 1964. Pl. 1, Fig. 10; PI. 2, Figs. 3, 4; Pl. 4, Fig. 2

Micula staurophora (Gardet) Stradner, 1963

Neochiastozygus concinnus (Martini) Perch-Nielsen, 1971. Pl. 1, Fig. 7

Neochiastozygus modestus Perch-Nielsen, 1971

Nephrolithus frequens Gorka, 1957

Octolithus multiplus (Perch-Nielsen) Romein, 1979

Prediscosphaera cretacea (Arkhangelsky) Gartner, 1968

Prediscosphaera spinosa (Bramlette and Martini) Gartner, 1968

Prediscosphaera stoveri (Perch-Nielsen) Shafif and Stradner, 197

Prinsius bisulcus (Stradner) Hay and Mohler, 1967. Pl. 3, Figs, 1-3, 8

Prinsius dimorphosus (Perch-Nielsen) Perch-Nielsen, 1977. Pl. 1, Figs. 1-6, 8

Prinsius martinii (Perch-Nielsen) Haq, 1977. Pl. 3, Fig. 1

Reinhardtites anthophorus (Deflandre) Perch-Nielsen, 1968

Toweius pertusus (Sullivan) Romein, 1979. Pl. 3, Figs. 5, 6, 9; PI. 4, Fig.

Zygodiscus sigmoides Bramlette and Sullivan, 1961. PI. 2, Figs. 2, 9

Zygodiscus spiralis Bramlette and Martini, 1964 
species overlap in stratigraphic range (see for example, PerchNielsen, 1985). Where the two taxa overlap in range, it was difficult to count the two species separately because the cross bars of many specimens are not well preserved to allow the identification of axial lines. However, it was possible to determine the first occurrence of $C$. bidens based on a few well preserved specimens which show axial lines in the cross bars.

Similarly, all Cruciplacolithus were counted as a group. This group consists predominantly of $C$. tenuis and $C$. primus with few specimens of $C$. edwardsii. Relative abundances of these species can be estimated according to the relatively well preserved specimens, and the relative abundances are recorded in the range chart.

A broad species concept of Coccolithus pelagicus is used in this study. It may include $C$. pelagicus (Wallich) Schiller, $C$. cavus Hay and Mohler, and C. eoplagicus (Bramlette and Riedel) Bramlette and Sullivan. It appears that all these species are synonymous.

Prinsius bisulcus and Prinsius martinii differ mainly by size, but the size difference has never been well defined. Where the two species co-occur, it is impossible to differentiate them consistently. Consequently, these two taxa were treated as one during the collection of the census data.

All species of Hornibrookina were counted as a group. This includes $H$. edwardsii Perch-Nielsen and $H$. teuriensis Edwards. Hornibrookina edwardsii is taken as a junior synonym of $H$. teuriensis (see taxonomic note below for detailed discussion). No Hornibrookina australis was found at Site 738.

The abundance of Thoracosphaera was not counted but estimated roughly and recorded in the range chart. The reason is that most specimens are broken, and it was not practical to count broken pieces when it was difficult to determine what percentage of the whole specimens they represent.

Due to small size $(2-4 \mu \mathrm{m})$ and poor preservation of Prinsius dimorphosus, this species was not counted. Only semiquantitative abundance estimates were recorded on the range chart.

All Cretaceous species were counted as one group, because individual species are rare and sporadic in the Danian section. These species are most likely to be redeposited, as discussed in the following text.

Because grouping and deletion of some species were necessary in this study, the limitations of the census data should be recognized and the interpretation of the results should take these factors into account.

Polar ordination analysis was made to determine how the assemblages change in relation to an axis defined by two endmember samples, one from the top of the section (Sample 119$738 \mathrm{C}-17 \mathrm{R}-1,15-16 \mathrm{~cm}, 341.45 \mathrm{mbsf})$, and the other one from the bottom of the Danian section (119-738C-20R-5, 35-36 cm, 376.55 mbsf). Polar ordination is an axial method for ordinating samples according to their similarity values along an axis defined by two end-member samples. A detailed description of this method has been given by Cisne and Rabe (1978).

In order to examine how the nannoplankton diversity changes through the Danian at Site 738, diversity indices were calculated for each sample. The measure used corresponds to the entropy concept of information theory proposed by Shannon (1949). In a paleoecological context, this measure is often referred to as the Shannon-Weaver diversity index $(\mathrm{H})$, which is calculated as

$$
\mathrm{H}=-\Sigma \mathrm{P}_{\mathrm{i}}\left(\log \mathrm{P}_{\mathrm{i}}\right)
$$

where $P_{i}$ is the probability of the occurrence of the $i^{\text {th }}$ species. Since $\mathrm{P}_{\mathrm{i}}$ is a parameter of the population and not the sample, it must be estimated by $\left(n_{i} / n\right)$, where $n_{i}$ is the number of specimens of the $\mathrm{i}^{\text {th }}$ species, and $\mathrm{n}$ is the total number of specimens counted in that sample.

\section{STRATIGRAPHIC DISTRIBUTION PATTERNS OF CALCAREOUS NANNOFOSSILS}

Stratigraphic distribution patters of calcareous nannofossils from Sample 119-738C-20R-CC (379.9 mbsf) to Sample 119738C-17R-1, $15 \mathrm{~cm}$ (341.15 mbsf), are presented in Table 2. Samples $119-738 \mathrm{C}-20 \mathrm{R}-5,96.1 \mathrm{~cm}$, and $-20 \mathrm{R}-\mathrm{CC}$ contain only Mesozoic calcareous nannofossil species, including the last Mesozoic zonal marker, Nephrolithus frequens, but no Cenozoic species, and should be placed in the uppermost Maestrichtian Zone NC23 of Roth (1978). A sharp peak of iridium concentration has been found in Sample 119-738C-20R-5, 96.0-96.2 cm ( $377.16 \mathrm{mbsf}$ ) (Schmitz, this volume), and this level is taken as the Cretaceous/Tertiary boundary. This chemically defined Cretaceous/Tertiary boundary is consistent with the nannofossil data, because the first Tertiary nannofossil marker, Biantholithus sparsus, was found only $13 \mathrm{~cm}$ above.

The next easily recognized datum is the first occurrence of Hornibrookina in Sample 119-738C-20R-5, $82.0 \mathrm{~cm}(377.02$ mbsf). This genus increases in abundance from few to abundant in less than $50 \mathrm{~cm}$ after its first appearance. The first Cruciplacolithus tenuis was found in Sample 119-738C-20R-5, $2 \mathrm{~cm}$ (376.22 mbsf). Abundant Prinsius dimorphosus were also first found in this sample. However, no Biscutum? romeinii, Biscutum parvulum or Toweius petalosus were found in this hole; thus the subdivision of NP1 as prescribed by Perch-Nielsen (1981) is not possible at Site 738. The first Coccolithus pelagicus was found in Sample 119-738C-20R-4, $117(375.87) \mathrm{cm}$. The first occurrence (FO) of this species was found at the same level as the FO of Prinsius dimorphosus in Tunisia (Perch-Nielsen, 1981a), one sample lower than the latter species event in Spain (Romein, 1979), and at Site 577 (Leg 86) in the northwest Pacific (Monechi, 1985), one-half zone lower than the latter datum in Turkey (Varol, 1989). As at Site 738, C. pelagicus occurs stratigraphically higher than $P$. dimorphosus at Site 690 in the Weddell Sea (Pospichal and Wise, 1990). This may suggest that $C$. pelagicus preferred warmer waters than $P$. dimorphosus and that the latitudinal temperature gradient in the early Paleocene caused the latitudinal diachroneity of the first occurrence of either one or both species.

The FO of Chiasmolithus danicus was observed in Sample 119-738C-19R-3, $85 \mathrm{~cm}$ (366.35 mbsf). According to Heck and Prins (1987), C. danicus evolved from Cruciplacolithus edwardsii, and the former species is only slightly younger than the latter. This sequence was also observed at Site 738 as well as at Site 690 in the Weddell Sea (Pospichal and Wise, 1990).

The FO of Prinsius martinii was located in Sample 119. 738C-18R-CC (360.50 mbsf). This datum was easy to pick because the species is abundant even at the beginning of its stratigraphic range. The first Toweius pertusus was also found in the same sample, and this species event may serve as a provisional secondary marker. The traditional marker species, Ellipsolithus macellus, was not found at Site 738. This is not surprising because the species is quite delicate and is usually not found in deep-sea sediments.

The next species event is the FO of Chiasmolithus bidens in Sample 119-738C-18R-1, $35 \mathrm{~cm}$ (351.25 mbsf). The first Fasciculithus tympaniformis and Prinsius bisulcus were found in the next higher sample (Sample 119-738C-17R-CC). Fasciculithus tympaniformis, as well as other species of Fasciculithus, are rare and sporadic in this part of the section at Site 738, thus making its application as a marker in the Antarctic region difficult.

Rare Hornibrookina teuriensis were present up to Sample 119-738C-16R-5, 97-98 cm, whereas Heliolithus kleinpellii was not found until Sample 119-738C-15R-CC (see Wei and Thierstein, this volume). The $\mathrm{LO}$ of $H$. teuriensis is used as a zonal 
Table 2. Distribution of calcareous nannofossils, Hole $738 \mathrm{C}$.

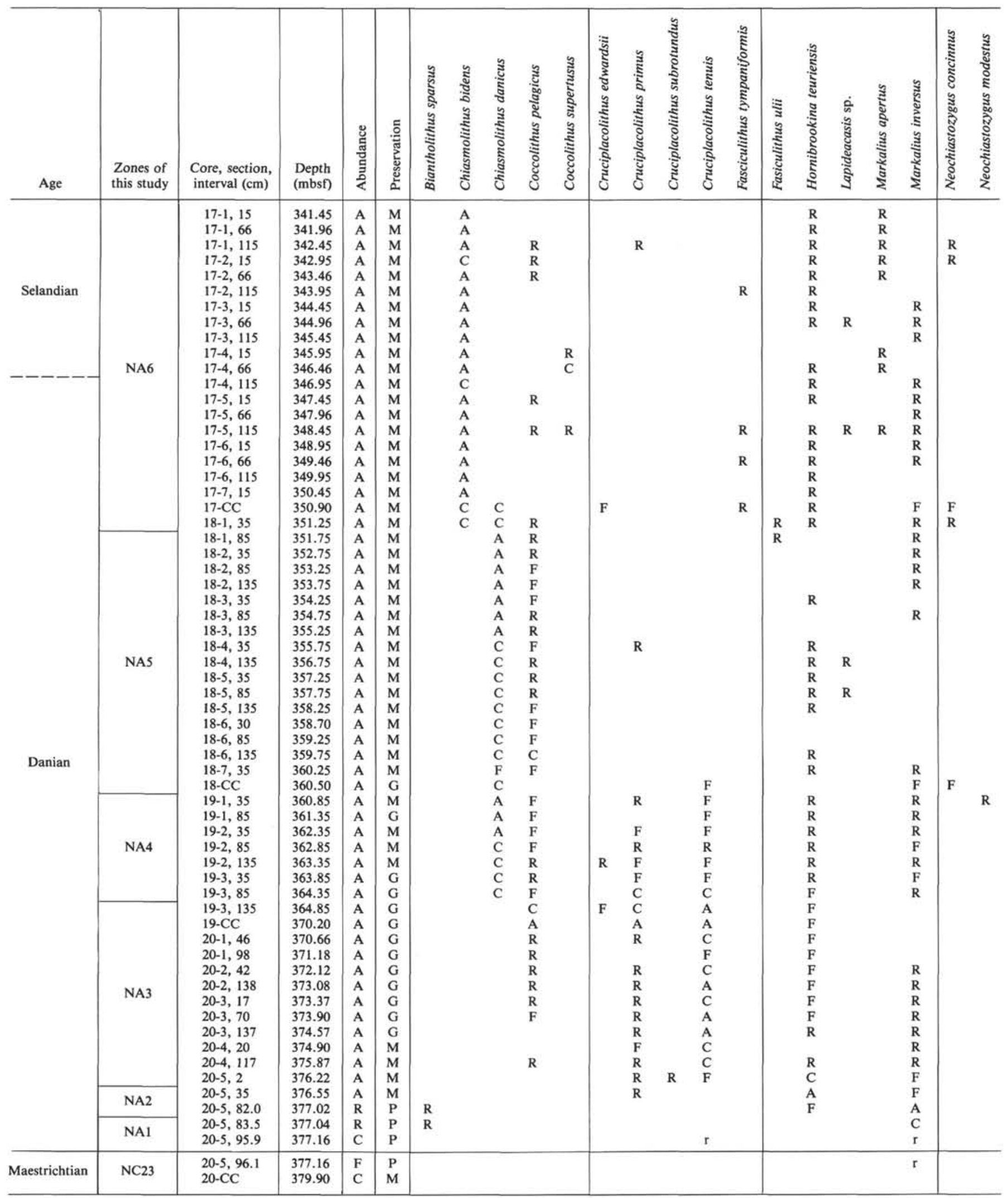

Note: Abundance is characterized: V, very abundant; A, abundant; C, common; F, few; R, rare. For preservation, G, good; M, moderate; P, poor. Lower-case letters indicate reworked specimens. 
Table 2 (continued).

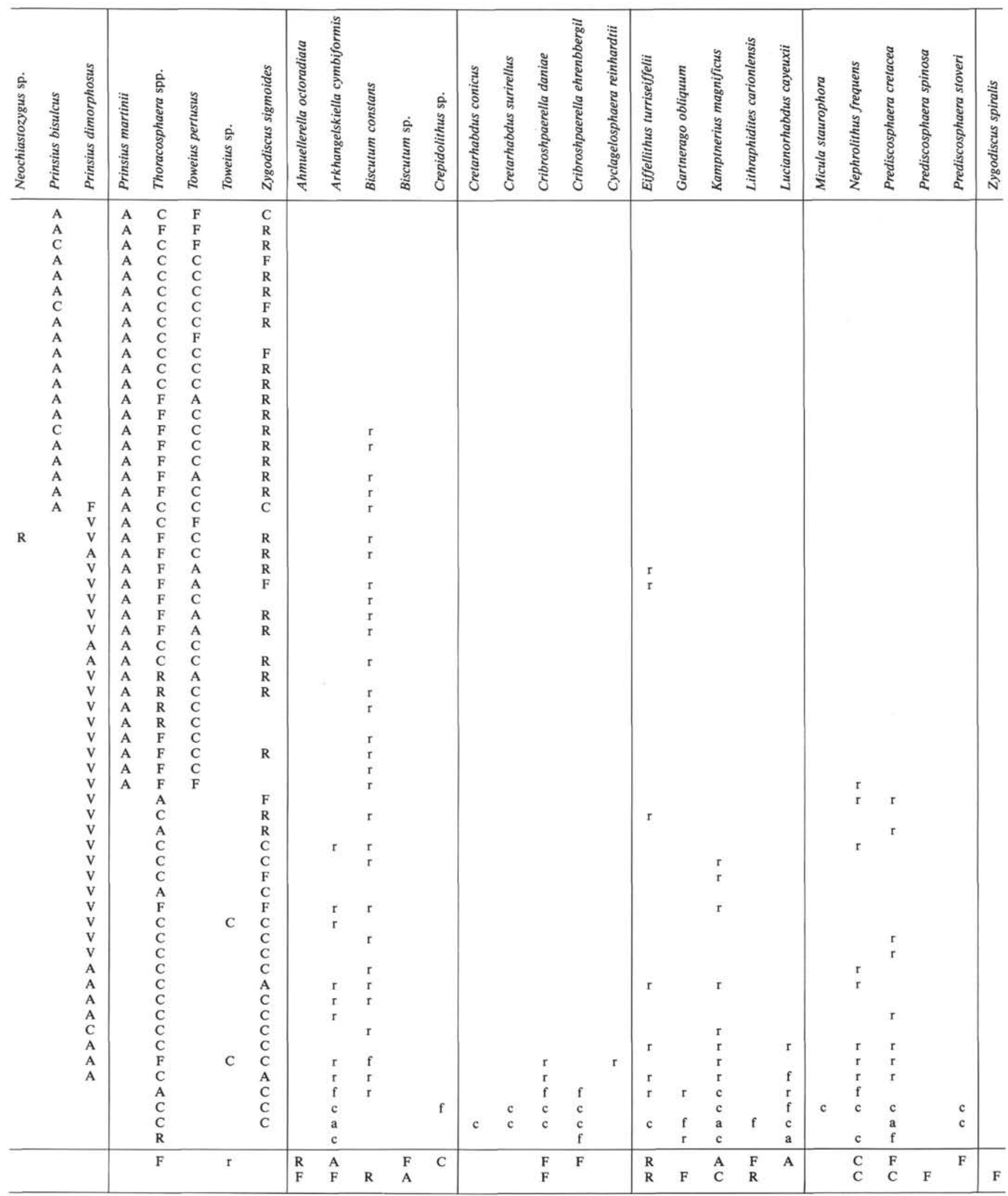


marker in this study. The zonal scheme is discussed in detailed below.

\section{ZONATION}

A number of calcareous nannofossil zonations for the Danian have been proposed since the detailed work of Hay and Mohler (1967). The most commonly used zonations are summarized in Figure 2. However, none of the previous zonations can achieve a satisfactory biostratigraphic resolution at Site 738 because of the rarity or absence of some conventional marker species (i.e., Ellipsolithus macellus, Fasciculithus tympaniformis) at this extreme high-latitude site. On the other hand, some nonconventional datums (i.e., the FO's of Hornibrookina, Prinsius martinii, and Chiasmolithus bidens) are useful for southern highlatitude biostratigraphy. Based on data from Site 738 (Table 2 and Fig. 3) and other Southern Ocean sites, particularly Site 690 in the Weddel Sea (Fig. 4), a calcareous nannofossil zonation for the Antarctic region is proposed. Each zone is prefixed by "NA" (short for "nannofossil Antarctic") and numbered from the bottom of the Danian upward. The zonation is summarized in Figure 2. The interpretation for the magnetostratigraphy of Hole $738 \mathrm{C}$ is poor at this moment due to large sampling gaps (Sakai and Keating, this volume). Future resampling of the cores for paleomagnetic measurement should produce a very useful magnetostratigraphy for this relatively complete high-latitude Danian sequence, and the nannofossil zones established in the present study can then be well correlated to the geomagnetic time scale. Detailed descriptions of the nannofossil zones proposed follow.

\section{Biantholithus sparsus Zone (NA1)}

Base. FO of Biantholithus sparsus or the iridium peak.

Top. FO of Hornibrookina.

Author. Perch-Nielsen (1979), emended by Wei and Pospichal (this paper).
Remarks. The base of this zone corresponds to the Cretaceous/Tertiary boundary. Martini (1971) defined the Cretaceous/Tertiary boundary by the last occurrence of Cretaceous forms. This criterion usually cannot be successfully applied because of reworking of Cretaceous assemblages into the lower Danian. Edwards (1973) proposed to use the FO of Conococcolithus panis to mark the Cretaceous/Tertiary boundary. This species is, however, a junior synonym of Biscutum constans (see Romein, 1977, p. 260, for detailed discussion). The latter species is well known to occur in the Cretaceous. Both Romein (1979) and PerchNielsen (1981a) used the beginning of Thoracosphaera acme to delimit the Cretaceous/Tertiary boundary. Though Perch-Nielsen et al. (1982) claimed that the Thoracosphaera acme is universally related to the base of the Tertiary, this is not the case in some areas (e.g., Monechi and Thierstein, 1985; Pospichal and Wise, 1990; this study). Perch-Nielsen (1979) used the FO of Biantholithus sparsus to define the Cretaceous/ Tertiary boundary. Biantholithus sparsus is the first true Tertiary species. The shortcoming of this marker for the Cretaceous/Tertiary boundary is that the species, as its name indicates, is generally very sparse. Consequently, it is difficult to determine precisely its evolutionary first appearance, and the boundary drawn by the FO of this species is often slightly higher than the chemically defined Cretaceous/Tertiary boundary. The iridium peak, if found, near and below the FO of $B$. sparsus, represents a more precise location of the Cretaceous/Tertiary boundary.

Hornibrookina first occurs just slightly above $(14 \mathrm{~cm})$ the Cretaceous/Tertiary boundary as defined by the iridium peak (Schmitz, this volume) at Site 738. This genus increases its abundance from few at its FO level to abundant less than $50 \mathrm{~cm}$ uphole. A similar phenomenon was also observed at Site 690 on Maud Rise, also an extreme southern high-latitude site $\left(65^{\circ} \mathrm{S}\right)$. With the quest for finer stratigraphic resolution of the Cretaceous/Tertiary boundary interval, the FO of Hornibrookina offers an easily picked and useful datum in the southern high latitudes. Assuming a uniform sedimentation rate for the interval be-

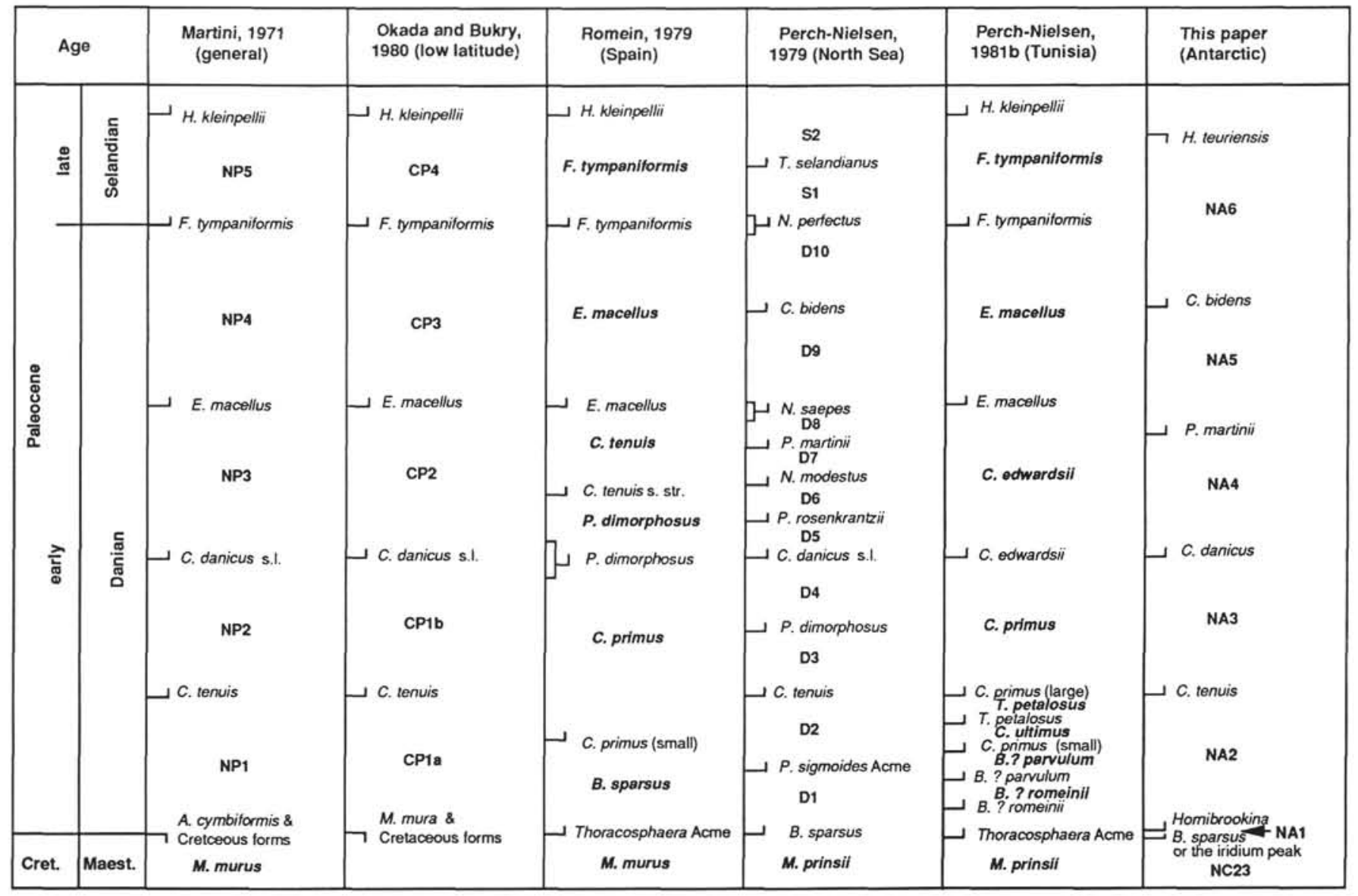

Figure 2. Correlation of nannofossil zonations of various authors (after Perch-Nielsen, 1985). 


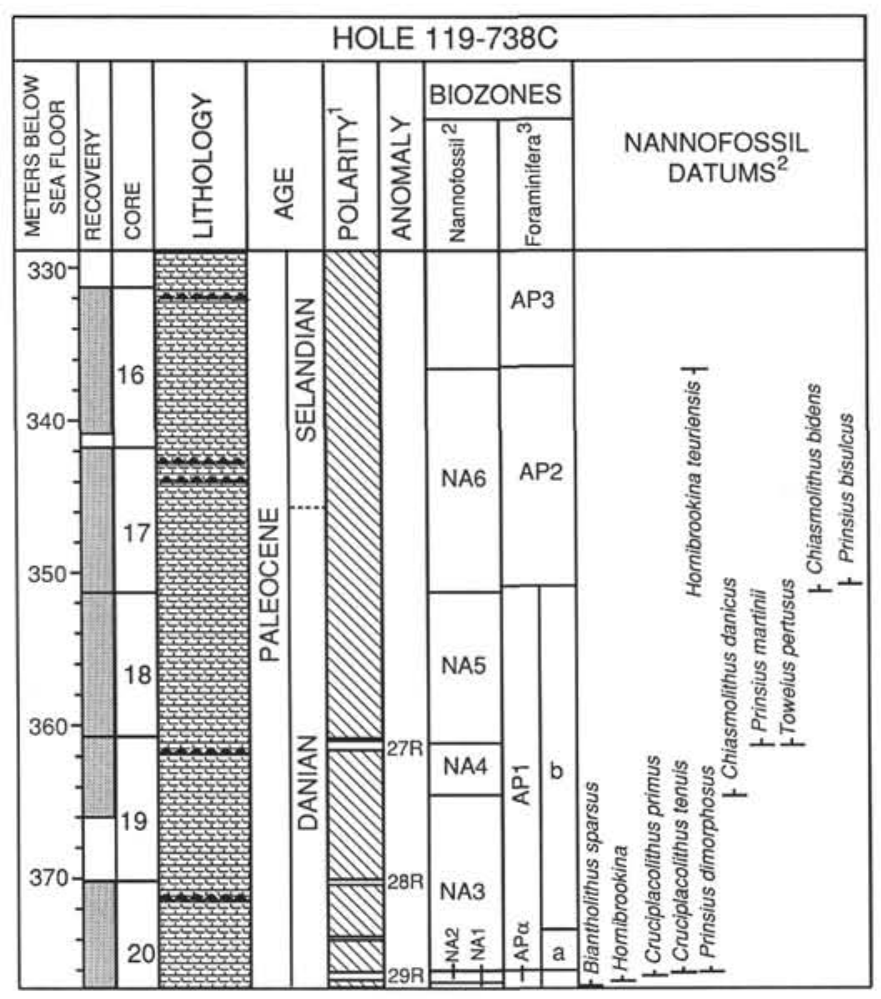

$\square$ recovered interval
chals chalk
chert nodule

Figure 3. Lithostratigraphy and magnetobiostratigraphy of the Danian and lower Selandian sequence recovered in Hole 738C. Data are taken from: ${ }^{1}$ Sakai and Keating (this volume); ${ }^{2}$ Wei and Pospichal (this paper); ${ }^{3}$ Huber (this volume).

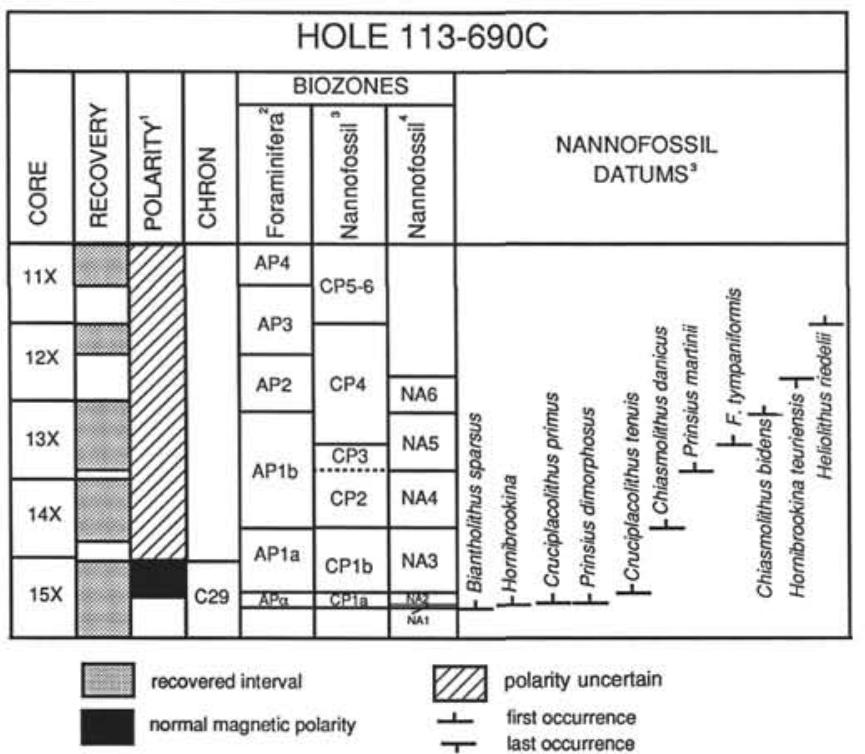

Figure 4. Magnetobiostratigraphy of the Danian and lower Selandian sequence recovered in Hole $690 \mathrm{C}$, a comparison hole for Hole $738 \mathrm{C}$. Data are taken from: ${ }^{1}$ Hamilton (1990); ${ }^{2}$ Stott and Kennett (1990); ${ }^{3}$ Pospichal and Wise (1990); also, ${ }^{3}$ Rezoned in the Antarctic zonation proposed in this paper. tween the iridium peak ( $377.16 \mathrm{mbsf}$ ) and the FO of Cruciplacolithus tenuis (376.38 mbsf), and an age of $66.4 \mathrm{Ma}$ for the iridium peak and 66.2 Ma for the FO of C. tenuis (Monechi and Thierstein, 1985) at Site 738, the FO of Hornibrookina would be $66.37 \mathrm{Ma}$.

\section{Hornibrookina teuriensis Zone (NA2)}

Top. FO of Cruciplacolithus tenuis

Base. FO of Hornibrookina

Author. Wei and Pospichal (this paper).

Remarks. This zone comprises most of Zone NP1 of Martini (1971) or Subzone CP1a of Okada and Bukry (1980). Perch-Nielsen (1981) subdivided Zone NP1 into five zones, using the FO's of Biscutum? romeinii, Biscutum? parvulum, Cruciplacolithus primus (small), and Toweius petalosus. Except for $C$. primus, none of these species were found at Site 738, probably due to exclusion of these species by low water temperatures at this Antarctic site. Cruciplacolithus primus first occurs within this zone. The FO of Prinsius dimorphosus can be used as a secondary marker to approximate that of $C$. tenuis.

Magnetostratigraphic data (Sakai and Keating, this volume) reveal that the FO of $C$. tenuis is within Subchron $29 \mathrm{R}$ at Site 738 , a similar situation as in the Contessa section in Italy (Monechi and Thierstein, 1985 ) but different from results of other sites (Subchron 29N, see Berggren et al., 1985). An age of 66.2 Ma (Monechi and Thierstein, 1985) is tentatively used in this study for the FO of $C$. tenuis.

\section{Cruciplacolithus tenuis Zone (NA3)}

Top. FO of Chiasmolithus danicus

Base. FO of Cruciplacolithus tenuis

Author. Mohler and Hay in Hay et al. (1967), emend. Martini (1970).

Remarks. The FO of C. danicus has an age of $64.8 \mathrm{Ma}$ at several DSDP sites (Berggren et al., 1985).

\section{Chiasmolithus danicus Zone (NA4)}

Top. FO of Prinsius martinii

Base. FO of Chiasmolithus danicus

Author. Martini (1970), emend. Edwards (1971).

Remarks. The base of this zone is the same as that of Zone NP3 of Martini (1971) or Zone CP2 of Okada and Bukry (1980). The top of the zone is different from the latter two zonations, where the FO of Ellipsolithus macellus is used instead. Ellipsolithus macellus is absent at Site 738 , as at Site 690 in the Weddell Sea. This delicate species is usually not present in deep-sea sediments. Further more, the FO of E. macellus is quite diachronous in different regions (Wei and Wise, 1989). On the other hand, Prinsius martinii is rather cosmopolitan. Though many authors do not differentiate Prinsius bisulcus from P. martinii (e.g., PerchNielsen, 1977; Okada and Thierstein, 1979; Percival, 1984; Monechi, 1985 ), the first occurrence of the $P$. bisulcus $-P$. martinii group has been consistently found between the FO of $\mathrm{C}$. danicus and the FO of Fasciculithus tympaniformis. The FO of $P$. martinii has an age of $63.8 \mathrm{Ma}$ in the Contessa section in Italy (Monechi and Thierstein, 1985).

\section{Prinsius martinii Zone (NA5)}

Top. FO of Chiasmolithus bidens

Base. FO of Prinsius martinii

Author. Edwards (1971), emend. Wei and Pospichal (this paper).

Remarks. In the high latitudes, the FO of $C$. bidens is closely associated with the FO of Prinsius bisulcus ( $>5 \mu \mathrm{m}$ ) and the LO of Prinsius dimorphosus. The latter two datums may serve as secondary markers. The FO of $C$. bidens has an age of about 63.2 Ma at DSDP Site 516 (Wei and Wise, 1989).

\section{Chiasmolithus bidens Zone (NA6)}

Top. LO of Hornibrookina teuriensis

Base. FO of Chiasmolithus bidens

Author. Wei and Pospichal (this paper).

Remarks. The $\mathrm{LO}$ of $H$. teuriensis has been found consistently to fall between the FO of Fasciculithus tympaniformis and the FO of Heliolithus kleinpellii at a number of localities, including the southern Kerguelen Plateau (this study), the Weddell Sea (Pospichal and Wise, 1990), the southwest Atlantic (Perch-Nielsen, 1977), and Turkey (Varol, 1989). It seems that the LO of $H$. teuriensis has a relatively consistent age over large areas. On the other hand, F. tympaniformis is rather rare and sporadic in the lower part of its stratigraphic range at Site 738 , making the 
precise location of the FO of this species impossible. Consequently, the top of Zone NP4 of Martini (1971) or Zone CP3 of Okada and Bukry (1980) is difficult to determine.

\section{RESULTS OF QUANTITATIVE ANALYSES}

The relative abundances of individual taxa in percent are given in the Appendix and are graphically presented in Figure 5. Cretaceous species drop from $100 \%$ below the Cretaceous/Tertiary boundary to less than $10 \%$ of the total assemblage $4 \mathrm{~m}$ above the boundary. Individual Cretaceous taxa are sporadically present uphole. Based on these distribution patterns, we consider these specimens of Cretaceous species to be reworked. Elsewhere, Cretaceous species in Danian sediments are considered to have survived the Cretaceous/Tertiary crisis (e.g., PerchNielsen et al., 1982; Smit and Romein, 1985). The evidence for that interpretation came from stable isotope studies of PerchNielsen et al. (1982). These authors measured oxygen and carbon isotopes of bulk samples from the uppermost Cretaceous and the lowermost Tertiary, and found strongly differing signals across the Cretaceous/Tertiary boundary. They believed that Cretaceous coccoliths constitute the bulk of the calcite measured, and thus concluded that the Cretaceous coccoliths in the basal Danian actually lived in the Tertiary. However, the bulk samples from the lowermost Danian usually contain a large amount of micrite, juvenile foraminifers, and pieces of Thoracosphaera, and the isotopic signals from these would overshadow those of Cretaceous nannofossil species in the lowermost Danian. Thus, the isotopic results from bulk-sample measurements by PerchNielsen et al. (1982) do not offer unambiguous evidence that the Cretaceous nannofossils found in the basal Danian actually lived into the Tertiary.

Cruciplacolithus registers a sudden bloom in Sample 119738C-20R-5, $2 \mathrm{~cm}$ (376.22 mbsf, Fig. 5, arrow 1), and makes up as much as $87 \%$ of the assemblage in less than $2 \mathrm{~m}$ uphole. This taxon maintains relatively high abundance up to about $360 \mathrm{mbsf}$, and is virtually absent (sporadic occurrence and less than $1 \%$ ) above that. Cruciplacolithus tenuis is the dominant species in the genus at Site 738, whereas Cruciplacolithus primus is considerably rarer compared to low- or middle-latitude sites. Semiquantitative data (Table 2) reveal that Prinsius dimorphosus begins to bloom virtually at the same time as Cruciplacolithus (Sample 119-738C-20R-5, $2 \mathrm{~cm}$ ). This a similar phenomenon found at Site 690 in the Weddell Sea (Pospichal and Wise, 1990). The next significant change in population composition is the abrupt increase (from $5 \%$ to $49 \%$ ) of Coccolithus pelagicus in Sample 119-738C-19R-CC (370.20 mbsf, Fig. 5, arrow 2). This species appears earlier but is relatively fewer in numbers (less than $6 \%$ ). The third large change in population composition is the addition of a new species, Chiasmolithus danicus, in Sample 119-738C-19R-3, $35 \mathrm{~cm}$ (363.85 mbsf, Fig. 5, arrow 3). The relative abundance of this species reaches up to $77 \%$ shortly after it appears. The final large change of population composition is in Sample 119-738C-18R-CC (360.5 mbsf), where Prinsius martinii and Toweius pertusus first occur (Fig. 5, arrow 4). The former species dominates the assemblage and reaches $85 \%$ of the total assemblage.

Figure 6 shows the results of the polar ordination analysis. Sample 119-738C-20R-5, 35-36 cm, from the bottom of the Danian was chosen as one end point and Sample 119-738C-17R-1, $15-16 \mathrm{~cm}$, from the top of the section was selected as the other end point in constructing the ordination axis onto which all samples were projected. The lower the value, the greater the similarity of the sample with Sample 119-738C-20R-5, 35-36 $\mathrm{cm}$, and the greater the dissimilarity of the sample with Sample $119-738 \mathrm{C}-17 \mathrm{R}-1,15-16 \mathrm{~cm}$. Four steps of floral change from the oldest assemblage represented by Sample 119-738C-20R-5, $36-37 \mathrm{~cm}$, to the youngest assemblage in Sample 119-738C-17R-1,
15-16 cm, are shown in Figure 6 (marked by arrows 1 through 4). These four steps are the same as those identified in Figure 5.

Changes of Shannon-Weaver diversity index values through time at Site 738 are presented in Figure 7. As pointed out in the preceding, because of the necessary grouping and deletion of some species in the census data as required by this study, the Shannon-Weaver diversity values given in the figure are conservative. However, it is clear that by about 371 mbsf (Zone NA3), the diversity has recovered to a level which is representative of the rest of the Danian section. The diversity index remains relatively stable above $360 \mathrm{mbsf}$, which may indicate relatively stable environmental conditions from late Danian to early Selandian time.

\section{PALEOBIOGEOGRAPHIC PATTERNS OF SELECTED TAXA}

Quantitative data on calcareous nannofossil assemblages of the Danian are still quite limited. Data for particular time-slices of the Danian have been presented by Haq and Lohmann (1976) and Haq et al. $(1977,1979)$. These data will be compared with those of the present study to reveal some paleobiogeographic patterns.

Except for two samples in Zone NA3, Coccolithus pelagicus has a relatively low abundance (a few percent) at Site 738 . Haq et al. $(1977,1979)$ showed that $C$. pelagicus constitutes $35 \%-$ $12 \%$ of the total assemblage from low to high (about $53^{\circ} \mathrm{N}$ ) latitudes for Zone NP3 (= NA4). For this time interval, Site 738 yielded less than $10 \%$ C. pelagicus. All these data are consistent with a general trend of decreasing $C$. pelagicus abundance toward higher latitudes. This trend is the reverse of that in the modern ocean, where $C$. pelagicus is most abundant in cool waters of the northern high-latitudes (McIntyre and Bé, 1967). This may indicate that $C$. pelagicus has undergone an evolutionary shift in its ecological response, as suggested by Haq and Lohmann (1976).

Haq and Lohmann (1976) reported Coccolithus subpertusus (Ericsonia subpertusa) as high as $47 \%$ in the low latitudes and as low as a few percent in the high latitudes. At Site 738, C. subpertusus only occurs sporadically. It thus seems that $C$. subpertusus also has a general trend of decreasing abundance toward higher latitudes and can be considered as a warm-water species.

Prinsius martinii and Prinsius bisulcus are very abundant at Site 738. This is contrary to the conclusion of Haq (1976) that Prinsius martinii is a boreal species that was confined to the northern high latitudes based on his observation of rare $P$. martinii at Site 323 (Leg 35) in the high-latitude South Pacific Ocean. In addition to Site 738, P. martinii and $P$. bisulcus were found to be abundant in other southern high-latitude localities, such as the Falkland Plateau in the South Atlantic (Wise and Wind, 1977) and Maud Rise in the Weddell Sea (Pospichal and Wise, 1990). Therefore, the conclusion that the northern high latitudes were cooler than the southern high latitudes during the Danian based on the rare $P$. martinii at Site 323 (Leg 35) (Haq, 1976) should be revised in light of the data available now.

Elsewhere, blooms of Thoracosphaera, Braarudosphaera, Cyclagelosphaera, Biscutum? romeinii, Biscutum? parvulum, Toweius petalosus, and Octolithus multiplus have been reported in Zones NP1 and NP2 (Perch-Nielsen, 1981a; Romein and Smit, 1981; Thierstein, 1981). All of these blooms have been found only in low or middle latitudes and some may be of only local significance. However, at the southern high-latitude Site 738, Thoracosphaera is significantly less abundant than in the lower latitudes, and no bloom of this taxon was recognized. No specimen of Braarudosphaera, Biscutum? parvulum, Biscutum? romeinii, Cyclagelosphaera, or Octolithus multiplus was found at Site 738. These taxa are also absent or very scarce at Sites 689 and 690 in the Weddell Sea (Pospichal and Wise, 1990). Since 


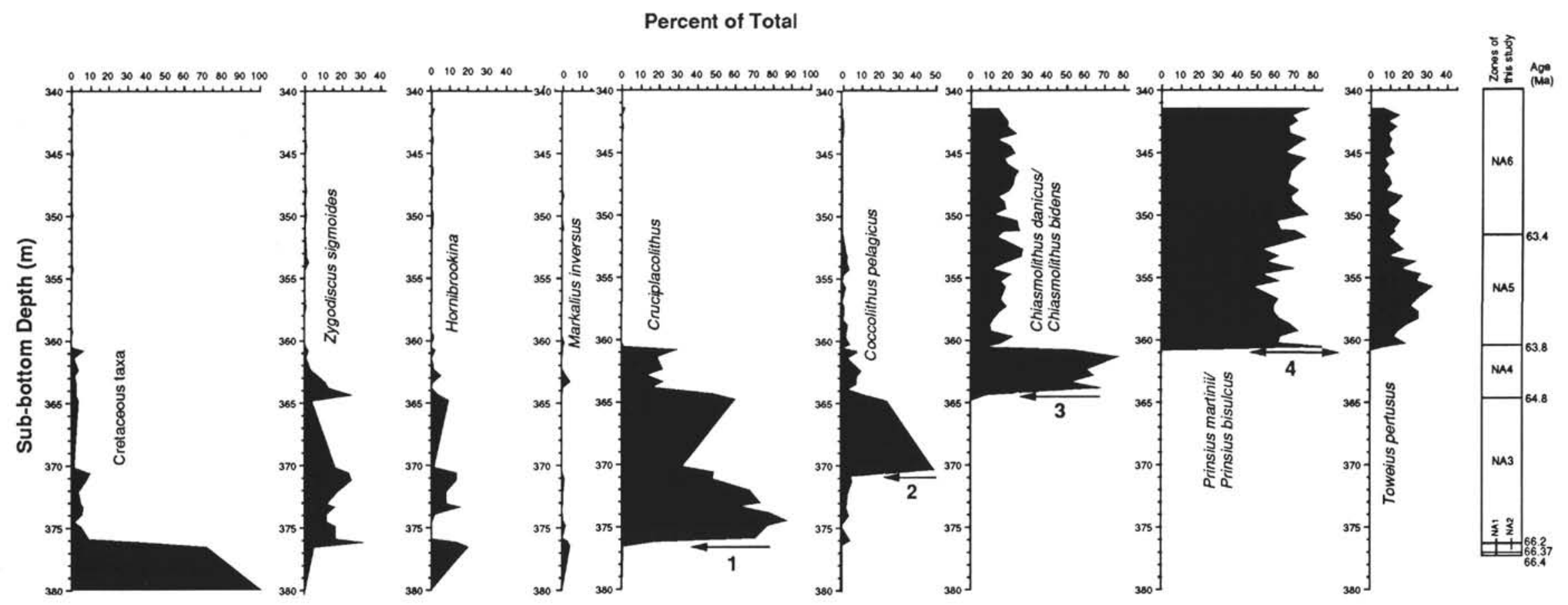

Figure 5. Changes of relative abundance of individual taxa through time at Site 738. Arrows 1 through 4 indicate four steps of large floral composition change. See zonation section for numerical age estimates. 


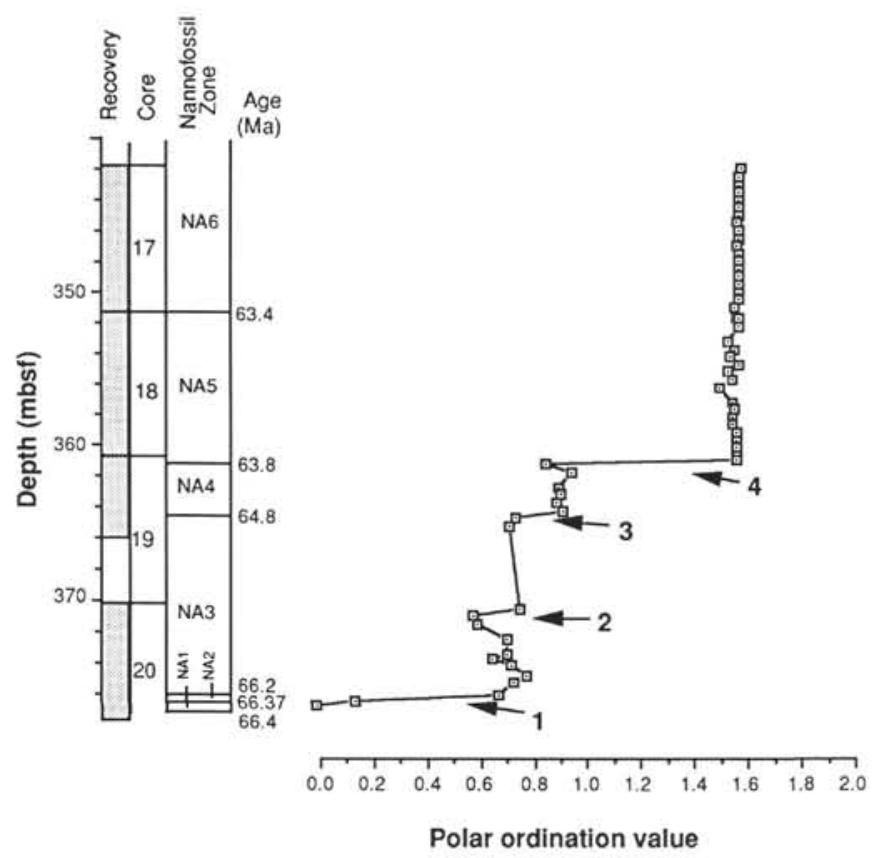

Figure 6. Polar ordination values of Site 738. The lower the value, the greater the similarity of the sample is in relation to Sample 119-738C$20 \mathrm{R}-5,35-36 \mathrm{~cm}$, and the greater the dissimilarity of the sample is in relation to Sample 119-738C-17R-1, 15-16 cm. Arrows 1 through 4 indicate four steps of large floral composition change. See zonation section for numerical age estimates.

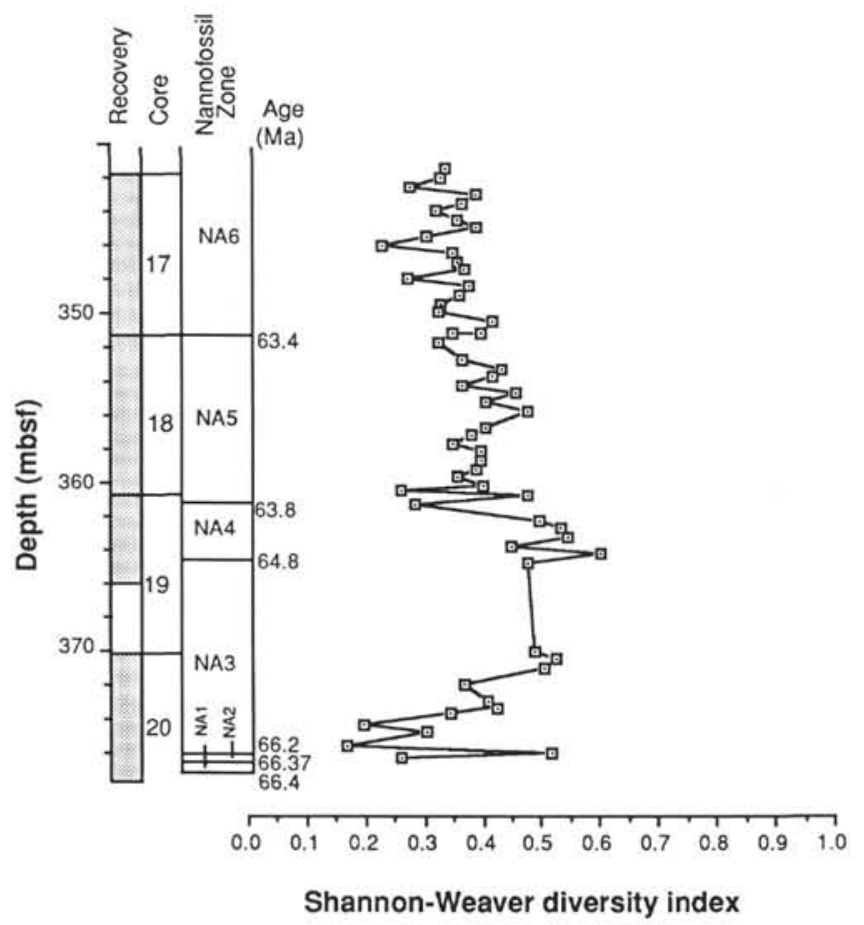

Figure 7. Changes of Shannon-Weaver diversity index through time at Site 738. See zonation section for numerical age estimates. the paleodepth of Site 738 was relatively shallow (about 1000 $\mathrm{m})$, the absence of these taxa was probably not due to preservational factors, but due to latitudinal differentiation of coccoliths in responding to the latitudinal thermal gradient in the Danian ocean. One distinct feature at Site 738 is the bloom of Hornibrookina shortly after the Cretaceous/Tertiary boundary extinction. This bloom appears to be a distinct southern highlatitude feature as it was also found in the Weddell Sea (Pospichal and Wise, 1990), but it has never been reported in middle or low latitudes.

\section{SUMMARY AND CONCLUSIONS}

The Danian section recovered at Site 738 is a biostratigraphically complete section divisible into six calcareous nannofossil zones. A southern high-latitude zonal scheme is proposed for the Danian, utilizing traditional markers and several nontraditional markers, i.e., FO's of Hornibrookina, Prinsius martinii, and Chiasmolithus bidens, and the LO of Hornibrookina teuriensis.

Quantitative analyses of calcareous nannofossil assemblages clearly indicate four large nannofloral changes, or steps, during the $1.6 \mathrm{~m} . \mathrm{y}$. interval after the Cretaceous/Tertiary boundary event. This rapid change of population is similar to that shown by the planktonic data from DSDP Site 577 (Leg 86) (Gerstel et al., 1987). The large and rapid changes of the planktonic biota may indicate unstable surface-water environments in the early Danian.

Taxa that bloom in low- or middle-latitude Danian sections, such as Braarudosphaera, Biscutum? parvulum, Biscutum? romeinii, Cyclagelosphaera, Octolithus multiplus, and Toweius petalosus, are absent at Site 738 , as they are in the Weddell Sea. On the other hand, Hornibrookina bloom shortly after the Cretaceous/Tertiary boundary at the Antarctic site. Cool-water taxa, such as Prinsius dimorphosus, Chiasmolithus danicus, Prinsius martinii, Chiasmolithus bidens, and Prinsius bisulcus are most abundant in the Antarctic region. This indicates a distinct latitudinal differentiation of nannofloral assemblages, which may suggest significant latitudinal thermal gradients in the Danian oceans.

\section{TAXONOMIC NOTES OF SELECTED SPECIES}

\section{Coccolithus subpertusus (Hay and Mohler) Wei and Pospichal, n. comb.}

Basionym. Ericsonia subpertusa Hay and Mohler, 1967, p. 1517, pl. 198, figs. 11, 15, 18; pl. 199, figs. 1-3; Roth, 1973, p. 730, pl. 12, fig. 5; Haq and Lohmann, 1976, pl. 1, figs. 7, 8; Perch-Nielsen, 1977, pl. 16, fig. 3; Romein, 1979, p. 212, pl. 2, fig. 6 .

Remarks. Bukry (1973, p. 676) was the first to point out that the genus Ericsonia is potentially a junior synonym of Coccolithus. Subsequently, Romein (1979, p. 105) and Wise (1983, p. 505) also presented reasons for this synonymy. Proximal views of Coccolithus pelagicus show the same three concentric cycles, as the type of Ericsonia, E. occidentalis, although the relative proportions of the cycles have been noted to differ. However, Wise $(1983$, p. 505, pl. 3) clearly showed that C. pelagicus changes the width of the outer proximal cycle with respect to that of the inner proximal cycle with time. It would be artificial to break the lineage between genera at some arbitrary point in the Paleogene or the Neogene based on the widths of the two proximal cycles, as proposed by Romein (1979). We agree with Wise (1983) that such a break should be made only to denote species or subspecies but not genera.

\section{Hornibrookina teuriensis Edwards, 1973}

Hornibrookina teuriensis Edwards, 1973, p. 77, figs. 22-37; Perch-Nielsen, 1977 , p. 816 , pl. 46, figs. 1, 4, 7-12.

Hornibrookina edwardsii Perch-Nielsen, 1977, p. 816, pl. 46, figs. 2, 3, 5, 6; p. 820, pl. 49, figs. 40-41.

Remarks. Perch-Nielsen (1977) proposed Hornibrookina edwardsii, which was believed to differ from $H$. teuriensis by a smaller central area and a row of protruding knobs around the central area. It is noted that 
the central area of $H$. edwardsii varies considerably, and seems not to be a useful criterion for separating $H$. edwardsii from $H$. teuriensis. The protruding knobs may be the result of diagenetic effects or intraspecific variation. Furthermore, the protruding knobs usually cannot be observed in the light microscope, rendering this criterion useless. In Leg 119 material, no differentiation of $H$. teuriensis and $H$. edwardsii was possible, and $H$. teuriensis is recorded in the range chart. Hornibrookina teuriensis ( $H$. edwardsii) bloomed shortly after the Cretaceous/Tertiary boundary at Maud Rise off East Antarctica (Pospichal and Wise, 1990) and at the Kerguelen Plateau, both extreme southern high-latitude areas. In the Brazos River section in Texas the species is present about $1 \mathrm{~m}$ above the Cretaceous/Tertiary boundary and is consistently rare (Jiang and Gartner, 1986).

\section{Prinsius bisulcus (Stradner) Hay and Mohler, 1967}

Coccolithus bisulcus Stradner, in Gohrbant, 1963, p. 72, pl. 8, figs. 3-6. Prinsius bisulcus (Stradner) Hay and Mohler, 1967, p. 1529, pl. 196, figs. $10-13$, pl. 197. fig. 6 ; Roth, 1973 , p. 732 , pl. 17 , fig. 2 ; Wise and Wind, 1976, pl. 6, figs. 3-6; Okada and Thierstein, 1979, p. 540, pl. 3, fig. 5; Monechi 1985, p. 339. pl. 11, fig. 1.

Prinsius martinii (Perch-Nielsen) Haq, Perch-Nielsen, 1977, p. 794, pl. 30, fig. 3 .

Remarks. This species is elliptical, with a lens-shaped centro-distal cycle (see Romein, 1979, p. 119, for terminology). The distal shield slopes at a relatively small angle, whereas in Toweius, the angle is much larger. Prinsius bisulcus has the same structure as P. martini (PerchNielsen) Haq but is larger (see Pl. 3, Fig. 1 of this paper for a comparison of the two species). Though no clear size differentiation has been established between the two species, specimens larger than $5.5 \mu \mathrm{m}$ are generally placed in $P$. bisulcus. This first species occurs later than $P$. martinii. The recognition of the two species is thus useful for biostratigraphic purposes.

\section{Prinsius dimorphosus (Perch-Nielsen) Perch-Nielsen, 1977}

Coccosphere, in Bramlette and Martini, 1964, p. 320, pl. 1, figs. 19, 20. Coccolithus(?) sp. in Martini, 1964, p. 52, pl. 2, figs. 5, 6.

Fossil coccosphere, in Black, 1965, p. 32, fig. 3.

Biscutum dimorphosus Perch-Nielsen, 1972, pl. 8, fig. 2.

Prinsius dimorphosus (Perch-Nielsen) Perch-Nielsen, 1977, p. 794, pl. 30 , fig. 10-13; Romein, 1979, p. 214, pl. 3, figs, 3-6.

Biscutum? tenuiculum Okada and Thierstein, 1979, p. 536, pl. 1, figs. 1,2 ; p. 552, pl. 9, figs. 1-8.

Prinsius rosenkrantzii Perch-Nielsen, 1979, p. 132, pl. 4, figs. 1-5.

Prinsius africanus Perch-Nielsen, 1981b, p. 854, pl. 3, 5, 6, 8, 9.

Prinsius tenuiculum (Okada and Thierstein) Perch-Nielsen, Wei and

Wise, 1989, p. 124, pl. 1, figs. 1, 2; p. 125, pl. 2, figs. 7, 8.

Remarks. This is a small-sized coccolith species (2-4 $\mu \mathrm{m})$ with a round or elliptical outline. Romein (1979) described the round specimens as type 1 and the elliptical as type 2 of Prinsius dimorphosus. Biscutum? tenuiculum Okada and Thierstein belongs to the round type of $P$. dimorphosus. The round and the elliptical types are gradational and usually occur together, although it appears that the elliptical types are more abundant in high-latitude sediments than in middle- or low-latitude sediments. The holotype of Prinsius rosenkrantzii Perch-Nielsen is round and is a junior synonym of $P$. tenuiculum (see Perch-Nielsen, 1984); the latter is in turn a junior synonym of $P$. dimorphosus. According to Perch-Nielsen (1981), Prinsius africanus Perch-Nielsen differs from $P$. tenuiculum by having a central netlike structure and a crown. However, the central netlike structure can only be seen in well-preserved material (isotypes of $P$. africanus do not show the netlike structure; see Perch-Nielsen, 1981, p. 854, pl. 3, figs. 6, 9) and a crown does exist in many typical $P$. dimorphosus specimens (see Pl. 1, Figs. 1 and 4). Therefore, $P$ africanus must be considered as a junior synonym of $P$. dimorphosus.

\section{Prinsius martinii (Perch-Nielsen) Haq, 1977}

Ericsonia? martinii Perch-Nielsen, 1969, p. 324, pl. 32, figs. 3b, 5-7. Prinsius martinii (Perch-Nielsen) Haq, 1971, p. 18, pl. 5, figs. 2, 3, 5, 10, non pl. 5, fig. 1; Romein, 1979, p. 214, pl. 3, figs. 7, 8.

non Prinsius martinii (Perch-Nielsen) Haq, Okada and Thierstein, 1979, p. 558, pl. 12 , figs. 12,14 .

Remarks. As pointed out above, Prinsius martinii has the same structure as $P$. bisulcus, but is smaller (4-5 $\mu \mathrm{m})$. Edwards (1971) first sug- gested the use of the first occurrence of $P$ martinii as a datum in the Danian. This datum has proved to be very useful in subsequent studies (e.g., Perch-Nielsen, 1979; Romein, 1979, Pospichal and Wise, 1990; this study).

\section{Toweius pertusus (Sullivan) Romein, 1979}

Coccolithus pertusus Sullivan, 1965, p. 32, pl. 3, figs. 5, 6.

Toweius craticulus Hay and Mohler, 1967, p. 1530, pl. 196, figs. 7-9; pl. 197, figs. 2, 3; Edwards and Perch-Nielsen, 1975, p. 502, pl. 3, figs. $3,6,8,9$; Perch-Nielsen, 1977, p. 794, pl. 30, fig. 4; Okada and Thierstein, 1979, p. 560, pl. 13, figs. 1, 2; Wise and Wind, 1977, p. 324 , pl. 6 , fig. 2 .

?Toweius eminens (Bramlette and Sullivan) Perch-Nielsen, Perch-Nielsen, 1977 , p. 794 , pl. 30 , fig. 6.

Toweius tovae Perch-Nielsen, 1971, p. 359 , pl. 13, figs. 1-3, 5, pl. 14, figs. 3, 9; Wise, and Wind, 1977, p. 322, pl. 5, fig. 6; p. 324, pl. 6, fig. 1; Okada and Thierstein, 1979, p. 560, pl. 13, figs. 5, 6; Monechi, 1985, p. 333, pl. 11, fig. 4.

Toweius sp. Wise and Wind, 1977, p. 326, pl. 7, fig. 1.

Remarks. As pointed out correctly by Romein (1979), Toweius craticulus Hay and Mohler is a junior synonym of Toweius pertusus (Sullivan) Romein. This species has six or more central pores. The number of central pores varies considerably, and is controlled in part by the degree of diagenetic overgrowth. Perch-Nielsen (1971) separated forms with six or seven pores from Toweius eminens (with four pores), naming them Toweius tovae. Romein (1979) placed $T$. tovae into synonymy with $T$. eminens. In our opinion, T. eminens is a distinct species with four central pores. Specimens of Toweius with five central pores are rare. On the other hand, there seems to be a continuous spectrum of variation in the central pores from six up. It is therefore appropriate to synonymize $T$. tovae with $T$. pertusus. Some specimens of $T$. pertusus are very elliptical and they are transitional to $P$. bisulcus (Pl. 3, Fig. 6, see also Edwards and Perch-Nielsen, 1975, p. 504, pl. 4, fig. 6).

\section{ACKNOWLEDGMENTS}

We are grateful to Professor Hans Thierstein, who kindly shared his information with us on the Cretaceous/Tertiary boundary studies of Site 738 and made helpful suggestions concerning this paper. He examined the core-catcher samples and samples from Section 119-738C-20R-5 aboard ship, and some of these data have been incorporated in this paper. We would also like to thank Professors Jack Baldauf, Timothy Bralower, and Sherwood Wise, and an anonymous reviewer for their most helpful reviews. This research was supported by grants from the U.S. Science Advisory Committee and a Florida State University Dissertation Fellowship to the first author. Equipment used was provided by NSF grant DPP89-17976 and a grant from the Amoco Foundation to S. W. Wise.

\section{REFERENCES}

Barron, J. A., Larsen, B., et al., 1989. Proc. ODP, Init. Repts., 119: College Station, TX (Ocean Drilling Program).

Berggren, W. A., Kent, D. V., and Flynn, J. J., 1985. Jurassic to Paleogene: Part 2. Paleogene geochronology and chronostratigraphy. In Snelling, N. J. (Ed.), The Chronology of the Geological Record: Geol. Soc. London Mem., 10:141-195.

Bramlette, M. N., and Martini, E., 1964. The great change in calcareous nannoplankton fossils between the Maestrichtian and Danian. Micropaleontology, 10:291-321.

Bukry, D., 1973. Coccolith stratigraphy, eastern equatorial Pacific, Leg 16, Deep Sea Drilling Project. In van Andel, T. H., Heath, G. R., et al., Init. Repts. DSDP, 16: Washington (U.S. Govt. Printing Office), 653-711.

Cisne, J. L., and Rabe, B. D., 1978. Coenocorrelation: gradient analysis of fossil communities and its applications in stratigraphy. Lethia, 11:342-363.

Edwards, A. R., 1966. Calcareous nannoplankton from the uppermost Cretaceous and the lowermost Tertiary of the Mid-Waipara section, South Island, New Zealand. N. Z. J. Geol. Geophys., 9:481-490.

1971. A calcareous nannoplankton zonation of the New Zealand Paleogene. In Farinacci, A. (Ed.), Proc. 2nd Planktonic Conf. Roma, 2:381-419. 
1973. Calcareous nannofossils from the southwest Pacific. In Burns, R. E., Andrews, J. E., et., Init. Repts. DSDP, 21: Washington (U.S. Govt. Printing Office), 641-691.

Gerstel, J., Thunell, R., and Ehrlich, R., 1987. Danian faunal succession: planktonic foraminiferal response to a changing marine environment. Geology, 15:665-668.

Hamilton, N., 1990. Mesozoic magnetostratigraphy of Maud Rise, Antarctica. In Barker, P. F., Kennett, J. P., et al., Proc. ODP, Sci. Results, 113: College Station, TX (Ocean Drilling Program), 255-260.

Haq, B. U., 1976. Coccoliths in cores from the Bellingshausen abyssal plain and Antarctic continental rise. In Hollister, C. D., Craddock, C., et al., Init. Repts. DSDP, 35: Washington (U.S. Govt. Printing Office), 557-567.

Haq, B. U., and Lohmann, G. P., 1976. Early Cenozoic calcareous nannoplankton biogeography of the Atlantic Ocean. Mar. Micropaleontol., 1:119-194.

Haq, B. U., Okada, H., and Lohmann, G. P., 1979. Paleobiogeography of the Paleocene/Eocene calcareous nannoplankton from the North Atlantic Ocean. In Tucholke, B. E., Vogt, P. R., et al., Init. Repts. $D S D P, 43$ : Washington (U.S. Govt. Printing Office), 617-629.

Haq, B. U., Perch-Nielsen, K., and Lohmann, G. P., 1977. Contribution to the Paleocene calcareous nannofossil biogeography of the central and southwest Atlantic Ocean (Ceara Rise and Sao Paulo Plateau, DSDP Leg 39). In Perch-Nielsen, K., Supko, P. R., et al., Init. Repts DSDP, 39: Washington (U.S. Govt. Printing Office), 841-848.

Hay, W. W., and Mohler, H. P., 1967. Calcareous nannoplankton from early Tertiary rocks at Pont Labau, France, and Paleocene-Eocene correlations. J. Paleontol., 41:1505-1541.

Jiang, M. J., and Gartner, S., 1986. Calcareous nannofossil succession across the Cretaceous/Tertiary boundary in east-central Texas. Micropaleontology, 32:232-255.

Loeblich, A. R., Jr., and Tappan, H., 1966. Annotated index and bibliography of the calcareous nannoplankton. Phycologia, 5:81-216. 1968. Annotated index and bibliography of the calcareous nannoplankton II. J. Paleontol., 42:584-598.

1969. Annotated index and bibliography of the calcareous nannoplankton III. J. Paleontol., 43:586-588.

1970a. Annotated index and bibliography of the calcareous nannoplankton Iv. J. Paleontol., 44:558-574.

$1970 \mathrm{~b}$. Annotated index and bibliography of the calcareous nannoplankton V. Phycologia, 9:157-174.

1971. Annotated index and bibliography of the calcareous nannoplankton VI. Phycologia, 10:315-339.

, 1973. Annotated index and bibliography of the calcareous nannoplankton VII. J. Paleontol., 47:715-759.

Martini, E., 1970. Standard Palaeogene calcareous nannoplankton zonation. Nature, 226:560-561.

1971. Standard Tertiary and Quaternary calcareous nannoplankton zonation. In Farinacci, A. (Ed.), Proc. 2nd Planktonic Conf. Roma, 2:739-785.

McIntyre, A., and Bé, A.W.H., 1967. Modern Coccolithophoridae of the Atlantic Ocean. I: placoliths and cyrtoliths. Deep-Sea Res. Oceanogr., 14:561-597.

Monechi, S., 1985. Campanian to Pleistocene calcareous nannofossil stratigraphy from the northwest Pacific Ocean, Deep Sea Drilling Project Leg 86. In Heath, G. R., Burckle, L. H., et al. Init. Repts. $D S D P$, 86: Washington (U.S. Govt. Printing Office), 301-336.

Monechi, S., and Thierstein, H. R., 1985. Late Cretaceous-Eocene nannofossil and magnetostratigraphic correlations near Gubbio, Italy. Mar. Micropaleontol., 9:419-440.

Okada, H., and Bukry, D., 1980. Supplementary modification and introduction of code numbers to the low-latitude coccolith biostratigraphic zonation (Bukry 1973, 1975). Mar. Micropaleontol., 5:321325.

Okada, H., and Thierstein, H. R., 1979. Calcareous nannoplanktonLeg 43, Deep Sea Drilling Project, In Tucholke, B. E., Vogt, P. R., et al., Init. Repts. DSDP, 43: Washington (U.S. Govt. Printing Office), 507-573.

Perch-Nielsen, K., 1969. Die Coccolithen einger danischer Maastrichtien und Danienlokalitaten. Bull. Geol. Soc. Den., 21:51-66.

1977. Albian to Pleistocene calcareous nannofossils from the western South Atlantic. In Perch-Nielsen, K., Supko, P. R., et al., Init. Repts. DSDP, 39: Washington (U.S. Govt. Printing Office), 699-823.
1979. Calcareous nannofossil zonation at the Cretaceous/ Tertiary boundary in Denmark. In Birkelund, T., and Bromley, R. G. (Eds.), Proc. Cretaceous-Tertiary Boundary Events Symp., Copenhagen, 1:115-135.

1981a. Les coccolithes du Paléocène près de El Kef, Tunisie et leurs ancêtres. Cah. Micropaleontol., 3:7-23.

1981b. New Maastrichtian and Paleocene calcareous nannofossils from Africa, Denmark, the USA and the Atlantic, and some Paleocene lineages. Eclogae Geol. Helv., 74:831-863.

Perch-Nielsen, K., McKenzie, J., and He, Q., 1982. Biostratigraphy and isotope stratigraphy and the "catastrophic" extinction of calcareous nannoplankton at the Cretaceous/Tertiary boundary. Spec. Pap.Geol. Soc. Am., 190:353-371.

Percival, S. F., Jr., 1984. Late Cretaceous to Pleistocene calcareous nannofossils from the South Atlantic, Deep Sea Drilling Project Leg 73. In Hsü, K. J., LaBrecque, J. L., et al., Init. Repts, DSDP, 73: Washington (U.S. Govt. Printing Office), 391-424.

Percival, S. F., Jr., and Fisher, A. G., 1977. Changes in calcareous nannoplankton in the Cretaceous-Tertiary biotic crisis at Zumaya, Spain. Evol. Theory, 2:1-35.

Pospichal, J., and Wise, S. W., Jr., 1990. Paleocene to middle Eocene calcareous nannofossils of ODP Sites 689 and 690, Maud Rise, Weddell Sea. In Barker, P. F., Kennett, J. P., et al., Proc. ODP, Sci. Results, 113: College Station, TX (Ocean Drilling Program), 613638.

Romein, A.J.T., 1977. Calcareous nannofossils from the Cretaceous/ Tertiary boundary interval in the Barranco del Gredero (Caravaca, Prov. Murcia, S. E. Spain), I and II. Proc. K. Ned. Akad. Wet., Ser. B: Palaeontol., Geol., Phys., Chem., B80:256-279.

, 1979. Lineages in early Paleogene calcareous nannoplankton. Utrecht Micropaleontol. Bull., 22:1-231.

Romein, A.J.T., and Smit, J., 1981. The Cretaceous/Tertiary boundary: calcareous nannofossils and stable isotopes. Proc. K. Ned. Akad. Wet., Ser. B: Palaeontol, Geol., Phys., Chem., 84:295-312.

Roth, P. H., 1978. Cretaceous nannoplankton biostratigraphy and oceanography of the northwestern Atlantic Ocean. In Benson, W. E., Sheridan, R. E., et al., Init. Repts. DSDP, 44: Washington (U.S. Govt. Printing Office), 731-760.

Shannon, C. E., 1949. The mathematical theory of communication. In Shannon, C. E., and Weaver, W. (Eds.), The Mathematical Theory of Communication: Chicago (Univ. Illinois Press), 29-125.

Smit, J., and Romein, A.J.T., 1985. A sequence of events across the Cretaceous-Tertiary boundary. Earth Planet. Sci. Lett., 74:155-170.

Steinmetz, J. C., 1985a. Bibliography and taxa of calcareous nannoplankton-V. INA Newsl., 7:5-28.

, 1985b. Bibliography and taxa of calcareous nannoplanktonVI. INA Newsl., 7:122-145.

, 1986. Bibliography and taxa of calcareous nannoplanktonVIII. INA Newsl., 8:66-87.

,1987a. Bibliography and taxa of calcareous nannoplanktonIX. INA Newsl., 9:8-29.

, 1987b. Bibliography and taxa of calcareous nannoplanktonX. INA Newsl., 9:81-109.

,1988a. Bibliography and taxa of calcareous nannoplanktonXI. INA Newsl., 10:7-29.

1988b. Bibliography and taxa of calcareous nannoplanktonXII. INA Newsl., 10:60-88.

1989. Bibliography and taxa of calcareous nannoplanktonXIII. INA Newsl., 11:6-23.

Stott, L., and Kennett, J. P., 1990. Antarctic Paleogene planktonic foraminifer biostratigraphy: ODP Leg 113, Sites 689 and 690. In Barker, P. F., Kennett, J. P., et al., Proc. ODP, Sci. Results, 113: College Station, TX (Ocean Drilling Program), 549-569.

Thierstein, H. R., 1981. Late Cretaceous nannoplankton and the change at the Cretaceous-Tertiary boundary. In Warme, J. E., et al., (Eds.), The Deep Sea Drilling Project: A Decade of Progress: Spec. Publ. Soc. Econ. Paleontol. Mineral., 32:355-394.

Thierstein, H. R., and Okada, H., 1979. The Cretaceous/Tertiary boundary event in the North Atlantic. In Tucholke, B. E., Vogt, P. R., et al., Init. Repts. DSDP, 43: Washington (U.S. Govt. Printing Office), 601-616.

van Heck, S. E., 1979a. Bibliography and taxa of calcareous nannoplankton. INA Newsl., 1:AB1-B27.

1979b. Bibliography and taxa of calcareous nannoplankton. INA Newsl., 1:ABV1-B42. 
,1980a. Bibliography and taxa of calcareous nannoplankton. INA Newsl., 2:5-34.

, 1980b. Bibliography and taxa of calcareous nannoplankton. INA Newsl., 2:43-81.

, 1981a. Bibliography and taxa of calcareous nannoplankton.

INA Newsl., 3:4-41.

, 1981b. Bibliography and taxa of calcareous nannoplankton.

INA Newsl., 3:51-86.

1982a. Bibliography and taxa of calcareous nannoplankton.

INA Newsl., 4:7-50.

1982b. Bibliography and taxa of calcareous nannoplankton.

INA Newsl., 4:65-96.

1983. Bibliography and taxa of calcareous nannoplankton. INA Newsl., 5:4-13.

van Heck, S. E., and Prins, B., 1987. A refined nannoplankton zonation for the Danian of the Central North Sea. Abh. Geol. Bundensanst. Austria, 39:285-303.

Varol, O., 1989. Paleocene calcareous nannofossil biostratigraphy. In Crux, J. A., and van Heck, S. E. (Eds.), Nannofossils and Their Applications: New York (Wiley), 267-310.
Wei, W., and Wise, S. W., Jr., 1989. Paleogene calcareous nannofossil magnetobiochronology: Results from South Atlantic DSDP Site 516. Mar. Micropaleontol., 14:119-152.

Wise, S. W., Jr., 1983. Mesozoic and Cenozoic calcareous nannofossils recovered by Deep Sea Drilling Project Leg 71 in the Falkland Plateau region, Southwest Atlantic Ocean. In Ludwig, W. J., Krasheninnikov, V. A., et al., Init. Repts. DSDP, 71: Washington (U.S. Govt. Printing Office), 481-550.

Wise, S. W., Jr., and Wind, F. H., 1977. Mesozoic and Cenozoic calcareous nannofossils recovered by DSDP Leg 36 drilling on the Falkland Plateau, Southwest Atlantic sector of the Southern Ocean. In Barker, P., Dalziel, I.W.D., et al. Init. Repts. DSDP, 36: Washington (U.S. Govt. Printing Office), 269-492.

Worsley, T. R., 1974. The Cretaceous/Tertiary boundary event in the ocean. In Hay, W. W. (Ed.), Studies in Paleo-oceanography, Soc. Econ. Paleontol. Mineral. Spec. Publ., 20:94-125.

Date of initial receipt: 4 October

Date of acceptance: 9 April 1990

Ms 119B-154 
APPENDIX

Percentage of Individual taxa

\begin{tabular}{|c|c|c|c|c|c|c|c|c|c|c|}
\hline $\begin{array}{l}\text { Core, section, } \\
\text { interval }(\mathrm{cm})\end{array}$ & $\begin{array}{l}\text { Depth } \\
\text { (mbsf) }\end{array}$ & C. bi/da & C. pel & Cruci & Horni & M. inv & P. mar & Towe & Z. sig & Creta \\
\hline $17-1,15$ & 341.45 & 14.4 & 0.0 & 0.9 & 0.9 & 0.0 & 76.6 & 6.8 & 0.0 & 0.5 \\
\hline $17-1,66$ & 341.96 & 16.5 & 0.0 & 0.0 & 0.0 & 0.0 & 69.0 & 14.5 & 0.0 & 0.0 \\
\hline $17-1,115$ & 342.45 & 19.1 & 0.5 & 0.0 & 0.2 & 0.0 & 71.2 & 9.0 & 0.0 & 0.0 \\
\hline $17-2,15$ & 342.95 & 19.1 & 0.4 & 0.4 & 0.0 & 0.0 & 66.8 & 13.4 & 0.0 & 0.0 \\
\hline $17-2,66$ & 343.46 & 23.3 & 0.4 & 0.0 & 0.0 & 0.0 & 67.5 & 8.8 & 0.0 & 0.0 \\
\hline $17-2,115$ & 343.96 & 13.6 & 0.0 & 0.0 & 0.3 & 0.0 & 75.3 & 10.8 & 0.0 & 0.0 \\
\hline $17-3,15$ & 344.45 & 20.4 & 0.0 & 0.0 & 0.0 & 0.0 & 69.8 & 9.5 & 0.4 & 0.0 \\
\hline $17-3,66$ & 344.96 & 22.5 & 0.0 & 0.0 & 0.0 & 0.0 & 65.0 & 12.1 & 0.0 & 0.4 \\
\hline $17-3,115$ & 345.45 & 17.3 & 0.0 & 0.0 & 0.0 & 0.0 & 75.6 & 7.1 & 0.0 & 0.0 \\
\hline $17-4,15$ & 345.95 & 19.0 & 0.0 & 0.0 & 0.0 & 0.0 & 72.1 & 8.9 & 0.0 & 0.0 \\
\hline $17-4,66$ & 346.46 & 24.7 & 0.0 & 0.0 & 0.5 & 0.0 & 68.4 & 6.3 & 0.0 & 0.0 \\
\hline $17-4,115$ & 346.95 & 22.9 & 0.0 & 0.0 & 0.0 & 0.0 & 67.6 & 9.6 & 0.0 & 0.0 \\
\hline $17-5,15$ & 347.45 & 22.4 & 0.0 & 0.0 & 0.0 & 0.0 & 66.7 & 10.9 & 0.0 & 0.0 \\
\hline $17-5,66$ & 347.96 & 19.6 & 0.0 & 0.0 & 0.0 & 0.0 & 71.8 & 8.0 & 0.6 & 0.0 \\
\hline $17-5,115$ & 348.45 & 14.6 & 0.0 & 0.0 & 0.0 & 0.6 & 68.4 & 16.4 & 0.0 & 0.0 \\
\hline $17-6,15$ & 348.95 & 17.6 & 0.0 & 0.0 & 0.0 & 0.0 & 68.6 & 13.7 & 0.0 & 0.0 \\
\hline $17-6,66$ & 349.46 & 17.9 & 0.0 & 0.0 & 0.0 & 0.0 & 72.8 & 9.3 & 0.0 & 0.0 \\
\hline $17-6,115$ & 349.95 & 12.2 & 0.0 & 0.0 & 0.4 & 0.0 & 76.7 & 9.8 & 0.4 & 0.4 \\
\hline $17-7,15$ & 350.45 & 24.2 & 0.0 & 0.0 & 0.5 & 0.0 & 60.3 & 15.1 & 0.0 & 0.0 \\
\hline $17-\mathrm{CC}$ & 351.18 & 25.3 & 0.0 & 0.0 & 0.0 & 0.5 & 62.9 & 11.3 & 0.0 & 0.0 \\
\hline $18-1,35$ & 351.25 & 16.8 & 0.0 & 0.0 & 0.0 & 0.0 & 70.6 & 12.6 & 0.0 & 0.0 \\
\hline $18-1,85$ & 351.75 & 13.8 & 0.8 & 0.0 & 0.0 & 0.0 & 75.6 & 9.8 & 0.0 & 0.0 \\
\hline $18-2,35$ & 352.75 & 27.2 & 2.0 & 0.0 & 0.0 & 0.3 & 52.4 & 17.0 & 0.7 & 0.3 \\
\hline $18-2,85$ & 353.25 & 26.5 & 2.7 & 0.0 & 0.0 & 0.0 & 61.1 & 9.2 & 0.5 & 0.0 \\
\hline $18-2,135$ & 353.75 & 18.3 & 2.3 & 0.0 & 0.0 & 0.0 & 55.0 & 22.9 & 1.5 & 0.0 \\
\hline $18-3,35$ & 354.25 & 10.9 & 3.9 & 0.0 & 0.0 & 0.0 & 69.0 & 15.5 & 0.0 & 0.8 \\
\hline $18-3,85$ & 354.75 & 20.5 & 0.9 & 0.0 & 0.0 & 0.0 & 52.7 & 25.9 & 0.0 & 0.0 \\
\hline $18-3,135$ & 355.25 & 15.5 & 0.0 & 0.0 & 0.0 & 0.0 & 60.8 & 23.7 & 0.0 & 0.0 \\
\hline $18-4,35$ & 355.75 & 18.2 & 1.8 & 0.0 & 0.0 & 0.0 & 48.2 & 31.8 & 0.0 & 0.0 \\
\hline $18-4,135$ & 356.75 & 15.5 & 0.0 & 0.0 & 0.0 & 0.0 & 60.8 & 23.7 & 0.0 & 0.0 \\
\hline $18-5,35$ & 357.25 & 18.6 & 1.1 & 0.0 & 0.0 & 0.0 & 59.0 & 20.8 & 0.5 & 0.0 \\
\hline $18-5,85$ & 357.75 & 14.8 & 1.0 & 0.0 & 0.0 & 0.0 & 59.0 & 25.2 & 0.0 & 0.0 \\
\hline $18-5,135$ & 358.25 & 12.1 & 0.4 & 0.0 & 0.0 & 0.0 & 62.4 & 25.1 & 0.0 & 0.0 \\
\hline $18-6,30$ & 358.70 & 10.4 & 2.8 & 0.0 & 0.0 & 0.0 & 67.9 & 18.9 & 0.0 & 0.0 \\
\hline $18-6,85$ & 359.25 & 10.6 & 2.7 & 0.0 & 0.0 & 0.0 & 71.7 & 14.2 & 0.0 & 0.9 \\
\hline $18-6,135$ & 359.75 & 21.7 & 2.4 & 0.0 & 1.2 & 0.0 & 62.7 & 12.0 & 0.0 & 0.0 \\
\hline $18-7,35$ & 360.25 & 15.8 & 4.0 & 0.0 & 0.0 & 1.0 & 61.4 & 17.8 & 0.0 & 0.0 \\
\hline $18-\mathrm{CC}$ & 360.50 & 5.6 & 0.2 & 0.9 & 0.0 & 0.4 & 85.3 & 6.6 & 0.5 & 0.5 \\
\hline $19-1,35$ & 360.85 & 53.7 & 7.8 & 28.3 & 2.0 & 0.4 & 0.0 & 0.0 & 2.0 & 5.9 \\
\hline $19-1,85$ & 361.35 & 76.5 & 3.1 & 18.9 & 0.0 & 0.0 & 0.0 & 0.0 & 5.0 & 1.0 \\
\hline $19-2,35$ & 362.35 & 60.5 & 10.1 & 21.6 & 1.4 & 0.0 & 0.0 & 0.0 & 2.9 & 3.5 \\
\hline $19-2,85$ & 362.85 & 63.8 & 7.6 & 13.3 & 4.8 & 1.9 & 0.0 & 0.0 & 6.7 & 1.9 \\
\hline $19-2,135$ & 363.35 & 52.4 & 8.1 & 21.5 & 0.6 & 4.0 & 0.0 & 0.0 & 10.7 & 2.7 \\
\hline $19-3,35$ & 363.85 & 66.3 & 2.5 & 15.3 & 0.0 & 0.6 & 0.0 & 0.0 & 12.7 & 2.5 \\
\hline $19-3,85$ & 364.35 & 8.4 & 12.9 & 48.4 & 3.9 & 0.0 & 0.0 & 0.0 & 23.9 & 2.6 \\
\hline $19-3,135$ & 364.85 & 0.0 & 24.4 & 59.7 & 9.2 & 0.0 & 0.0 & 0.0 & 3.4 & 3.4 \\
\hline 19-CC & 370.20 & 0.0 & 49.3 & 31.8 & 1.2 & 0.0 & 0.0 & 0.0 & 16.2 & 1.5 \\
\hline $20-1,46$ & 370.66 & 0.0 & 5.0 & 48.7 & 13.4 & 0.0 & 0.0 & 0.0 & 23.5 & 9.4 \\
\hline $20-1,98$ & 371.18 & 0.0 & 5.2 & 48.1 & 13.0 & 1.3 & 0.0 & 0.0 & 24.7 & 7.8 \\
\hline $20-2,42$ & 372.12 & 0.0 & 2.9 & 67.7 & 8.0 & 0.3 & 0.0 & 0.0 & 17.5 & 3.6 \\
\hline $20-2,138$ & 373.08 & 0.0 & 2.6 & 73.1 & 7.9 & 0.7 & 0.0 & 0.0 & 11.2 & 4.6 \\
\hline $20-3,17$ & 373.37 & 0.0 & 2.4 & 61.9 & 14.3 & 0.0 & 0.0 & 0.0 & 15.5 & 6.0 \\
\hline $20-3,70$ & 373.90 & 0.0 & 3.5 & 77.8 & 2.1 & 0.0 & 0.0 & 0.0 & 11.1 & 5.6 \\
\hline $20-3,137$ & 374.57 & 0.0 & 0.0 & 86.9 & 0.0 & 0.6 & 0.0 & 0.0 & 11.3 & 1.3 \\
\hline $20-4,20$ & 374.90 & 0.0 & 0.0 & 77.3 & 0.0 & 1.6 & 0.0 & 0.0 & 16.4 & 4.7 \\
\hline $20-4,117$ & 375.87 & 0.0 & 4.0 & 70.7 & 0.2 & 0.0 & 0.0 & 0.0 & 16.0 & 9.0 \\
\hline $20-5,2$ & 376.22 & 0.0 & 0.0 & 17.4 & 13.0 & 3.1 & 0.0 & 0.0 & 28.6 & 37.9 \\
\hline $20-5,35$ & 376.55 & 0.0 & 0.0 & 0.4 & 19.0 & 4.1 & 0.0 & 0.0 & 4.5 & 71.9 \\
\hline $20-\mathrm{CC}$ & 379.90 & 0.0 & 0.0 & 0.0 & 0.0 & 0.0 & 0.0 & 0.0 & 0.0 & 100.0 \\
\hline
\end{tabular}

Note: Depth is expressed as meters below seafloor $(\mathrm{mbsf}) . \mathrm{C} . \mathrm{di} / \mathrm{da}=$ Chiasmolithus bidens $/$ C. danicus; $\mathrm{C}$. pel $=$ Coccolithus pelagicus; Cruci $=$ Crucipalcolithus; Horni $=$ Hornibrookina; $\mathrm{M}$. inv $=$ Markalius inversus; $\mathbf{P}$. mar $=$ Prinsius martinii $/ P$. bisulcus; Towe $=$ Toweius pertusus $;$ Z. sig $=$ Zygodiscus sigmoides $;$ Creta $=$ Cretaceous taxa. 


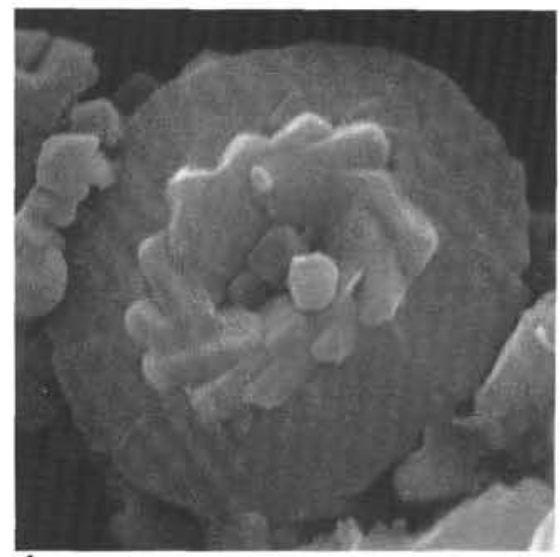

1

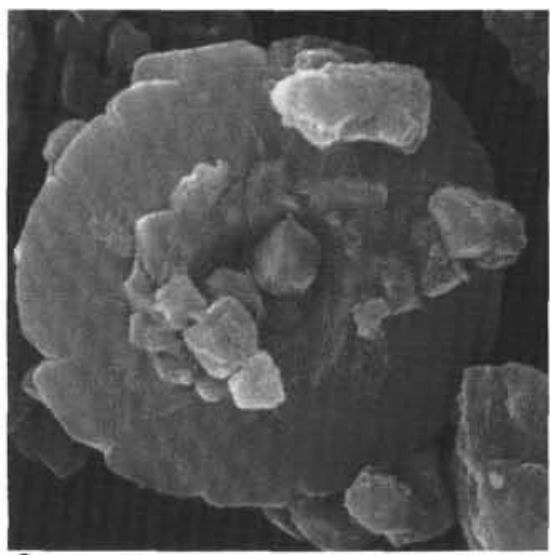

2

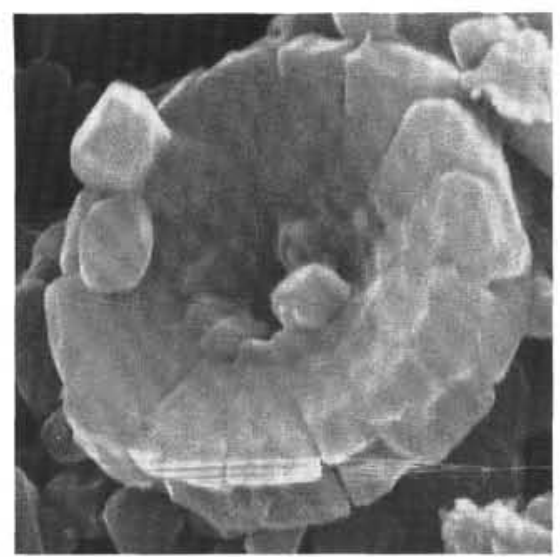

3

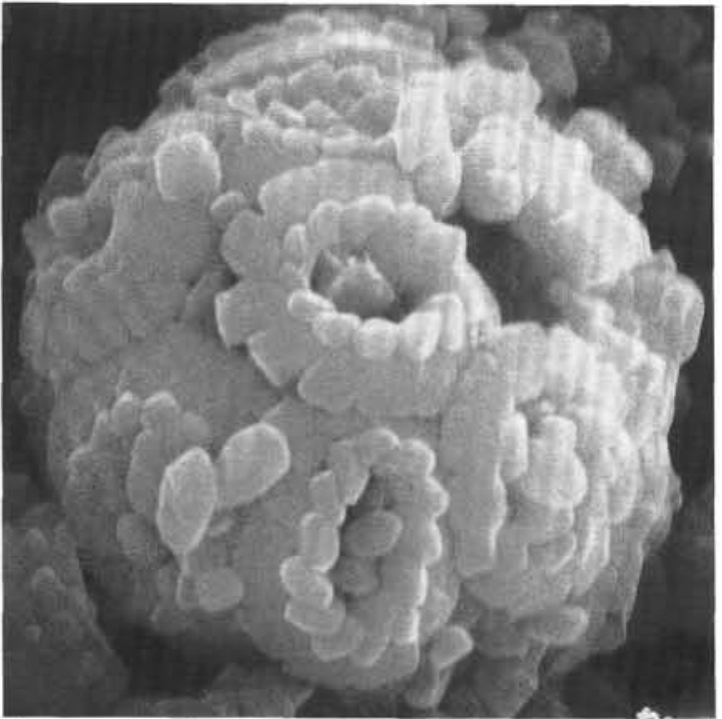

4

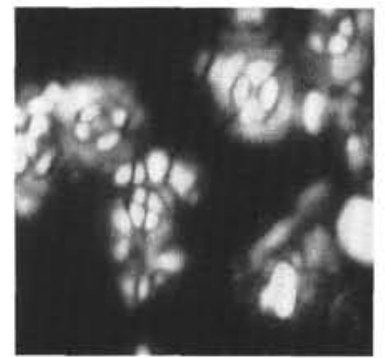

6

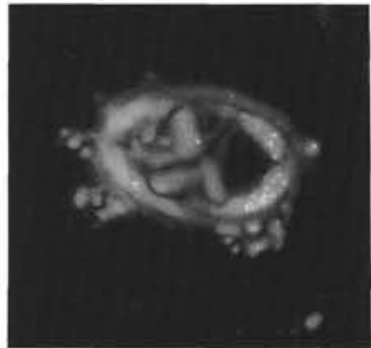

7

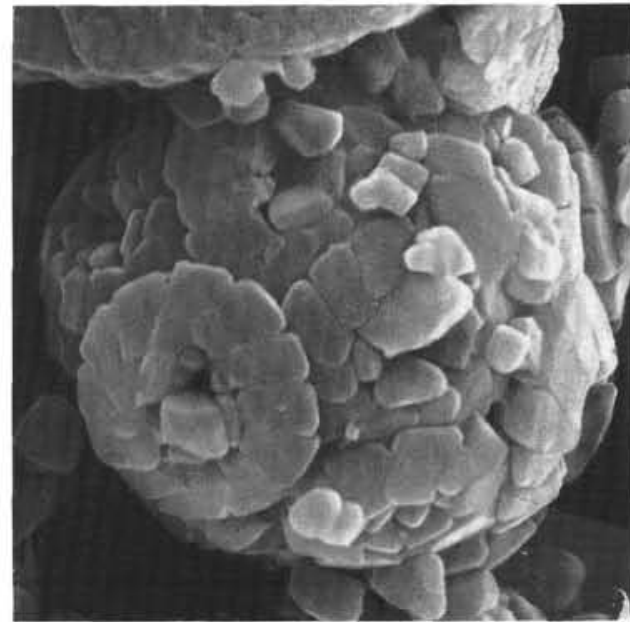

5

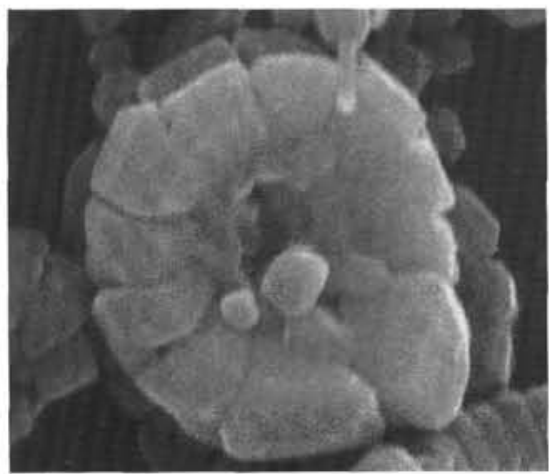

8

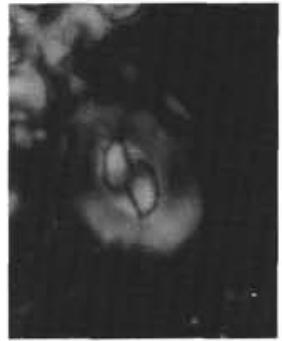

9

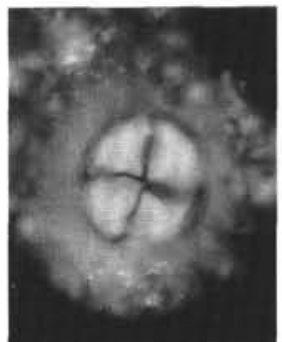

10

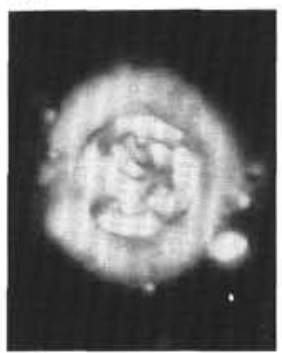

11

Plate 1. 1-6, 8. Prinsius dimorphosus (Perch-Nielsen) Perch-Nielsen. (1) Distal view, elliptical type, Sample 119-738C-19R-CC, 15,000 $\times$; (2) distal view, elliptical type, Sample 119-738C-19R-CC, 13,000×; (3) proximal view, round type, Sample 119-738C-20R-1, 46-47 cm, 15,000 $\times$; (4) coccosphere, elliptical type, Sample 119-738C-18R-7, 55-56 cm, 10,500×; (5) coccosphere, round type, Sample 119-738C-20R-4, 20-21 cm, 11,000 $\times$; (6) both elliptical an round types, Sample 119-738C-19R-3, 85-86 cm, 3,000 $;$; $(8)$ round type, Sample $119-738 \mathrm{C}-18 \mathrm{R}-7,35-36 \mathrm{~cm}, 15,000 \times$. 7. Neochiastozygus concinnus (Perch-Nielsen) Perch-Nielsen, Sample 119-738C-20R-5, 135-136 cm, 2,500×. 9. Biscutum constans (Gorka) Black, Sample 119-738C-20R-5, 35-36 cm, 2,500×. 10. Markalius inversus (Deflandre) Bramlette and Martini, Sample 119-738C-18R-1, 135-136 cm, 2,500 . 11. Markalius apertus Perch-Nielsen, Sample 119-738C-17R, 66-67 cm, 2,500×. 


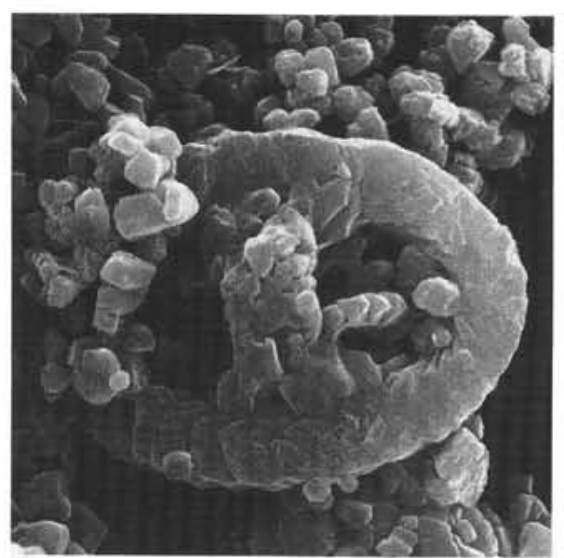

1

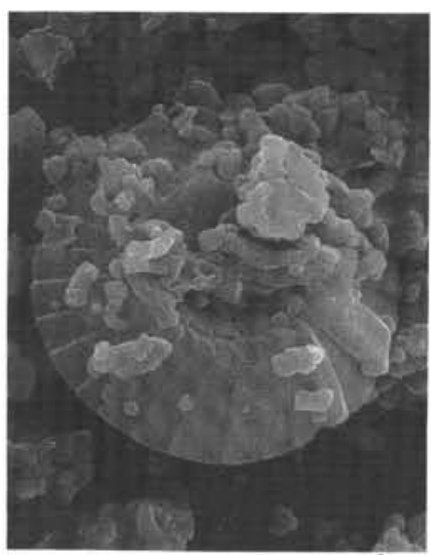

4

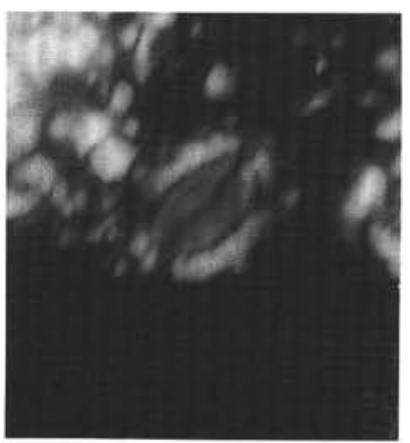

7

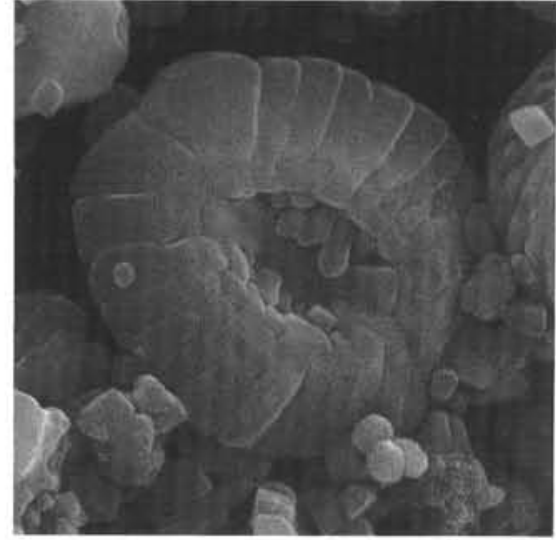

2

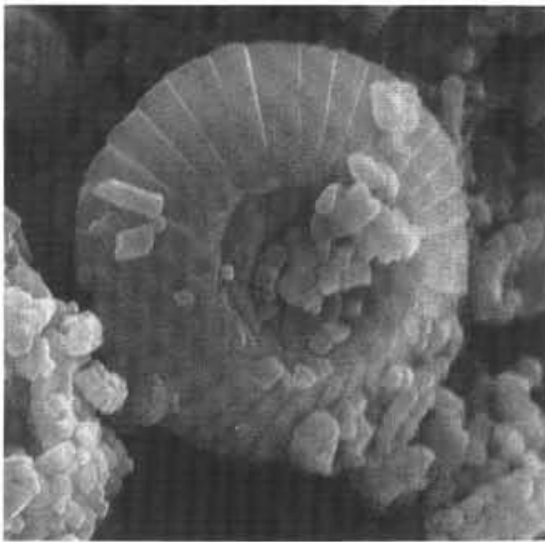

3

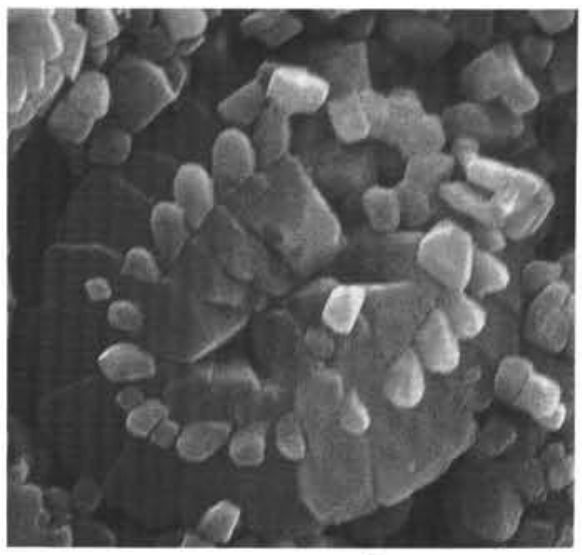

5

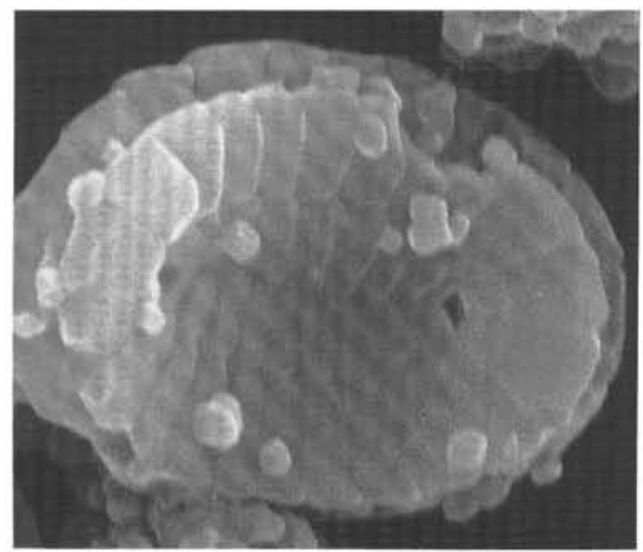

6
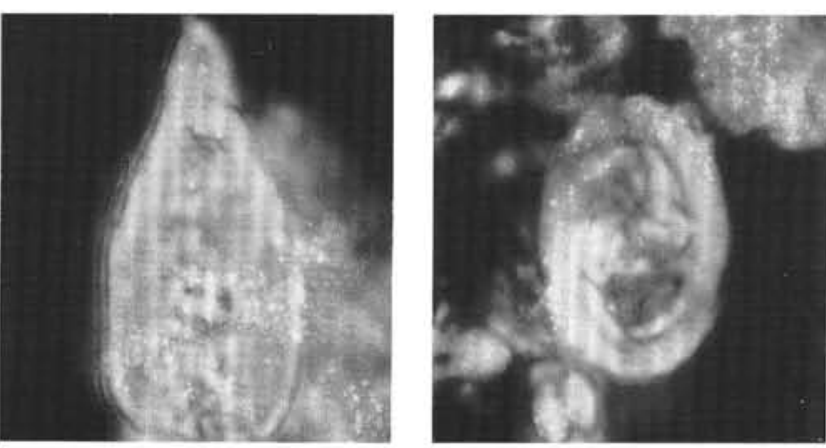

9

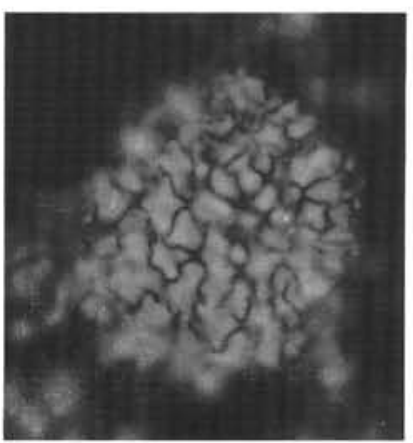

10

Plate 2. 1, 9. Zygodiscus sigmoides Bramlette and Sullivan. (1) Distal view, Sample 119-738C-20R-4, 20-21 cm, 6,000 $\times$; (9) Sample 119-738C-19R$\mathrm{CC}, 6,000 \times$. 2. Biscutum constans (Gorka) Black, distal view, Sample $119-738 \mathrm{C}-18 \mathrm{R}-7,35-36 \mathrm{~cm}, 7,000 \times$. 3, 4. Markalius inversus (Deflandre) Bramlette and Martini (3) Distal view, Sample 119-738C-18R-7, 35-36 cm, 4,500×; (4) Sample 119-738C-19R-1, 35-36 cm, 4,500× . 5-7. Hornibrookina teuriensis Edwards. (5) Distal view, Sample 119-20R-1, 46-47 cm, 8,500×; (6) proximal view, Sample 119-738C-19R-1, 35-36 cm, 9,500×; (7) Sample 119-738C-20R-5, 35-36 cm, 2,500×. 8. Lapideacassis sp., Sample 119-738C-18R-5, 85-86 cm, 2,500×. 10. Thoracosphaera sp., Sample $119-738 \mathrm{C}-19 \mathrm{R}-2,135-136 \mathrm{~cm}, 2,500 \times$. 


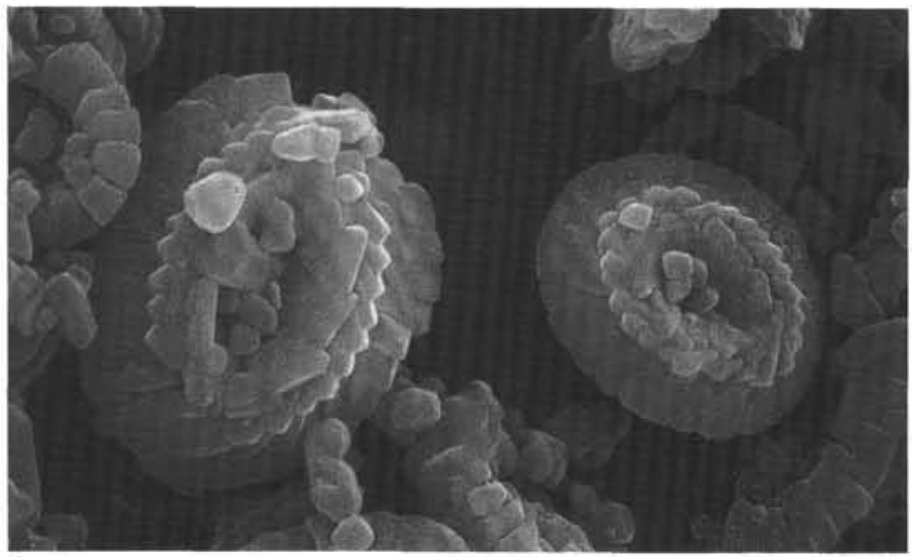

1

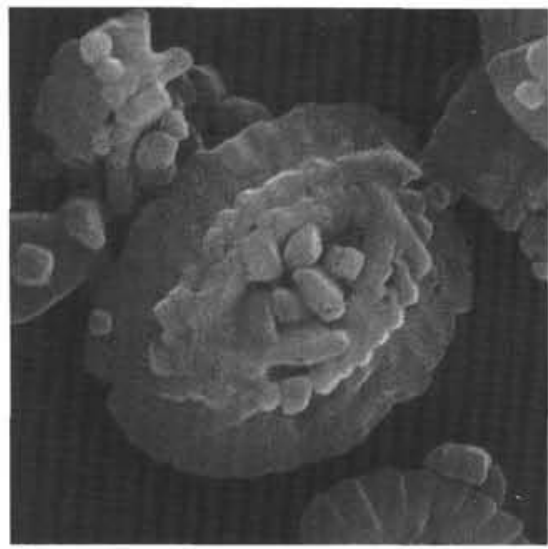

3

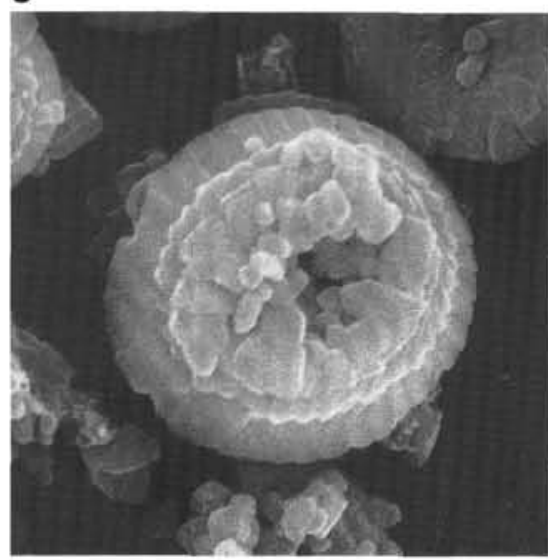

5

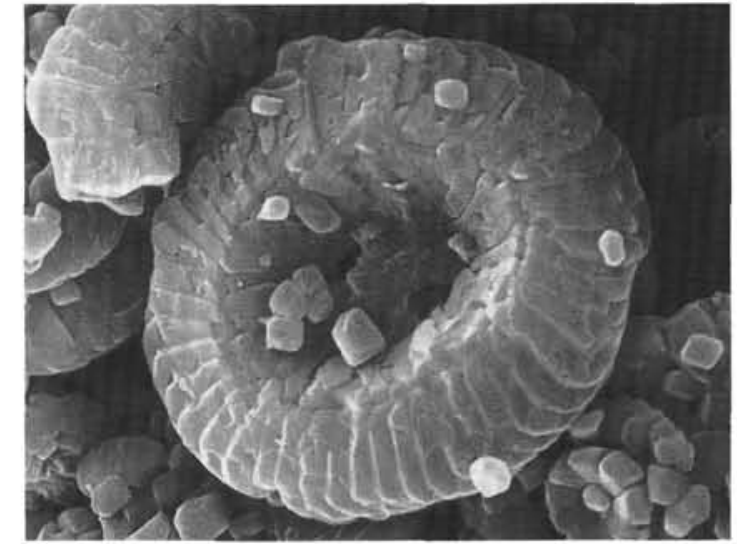

\section{4}

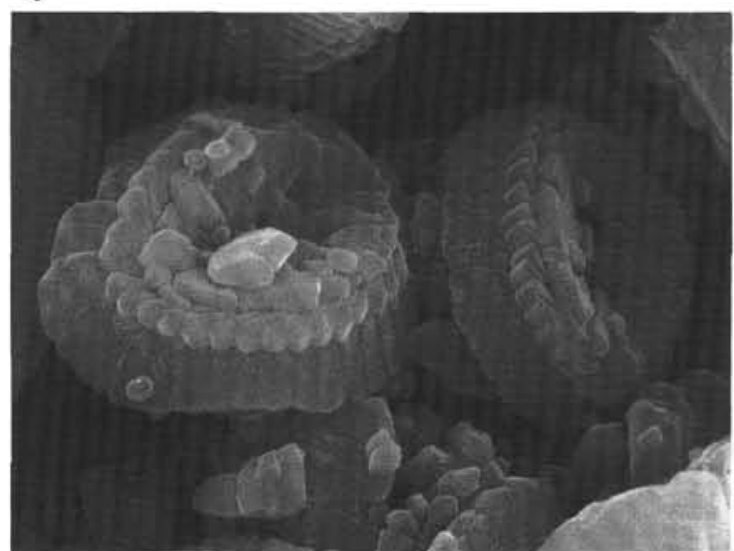

6

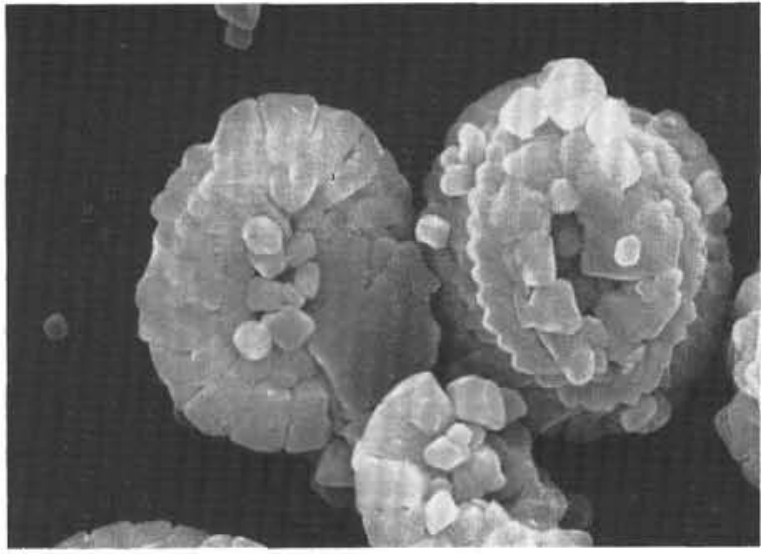

2

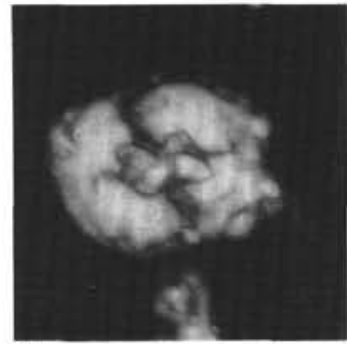

7

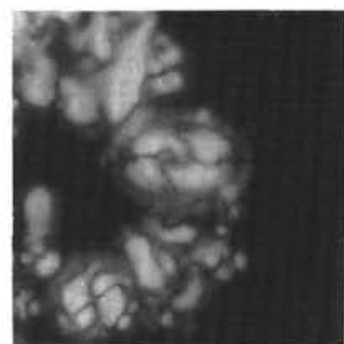

8

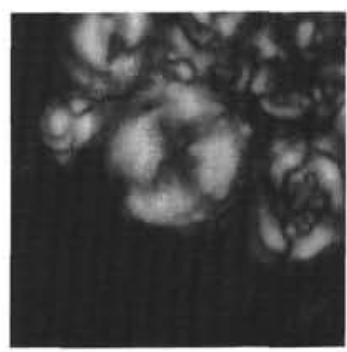

9

Plate 3. 1. Prinsius bisulcus (Stradner) Hay and Mohler on left, Prinsius martinii (Perch-Nielsen) Haq on right, both distal view, Sample 119-738C17R-5, 15-16 cm, 8,500× . 2, 3, 8. Prinsius bisulcus (Stradner) Hay and Mohler. (2) Proximal view on left, distal view on right, Sample 119-738C18R-CC, 7,500 × (3) distal view, Sample 119-738C-17R-5, 15-16 cm, 9,500×; (8) Sample 119-738C-18R-2, 135-136 cm, 2,500 × 4, 7. Cruciplacolithus edwardsii Romein. (4) Distal view, Sample 119-738C-19R-3, 135-136 cm, 6,500×; (7) Sample 119-738C-19R-2, 85-86 cm, 2,500×. 5, 6, 9. Toweius pertusus (Sullivan) Romein. (5) Distal view, Sample 119-738C-17R-5, 15-16 cm, 6,500×; (6) distal view, Sample 119-738C-17R-5, $15-16 \mathrm{~cm}, 8,000 \times$, both specimens are elliptical; (9) Sample 119-738C-182, 135-136 cm, 2,500×. 


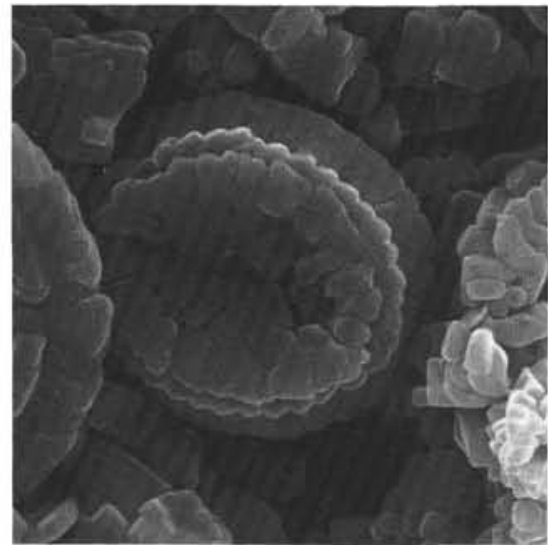

1

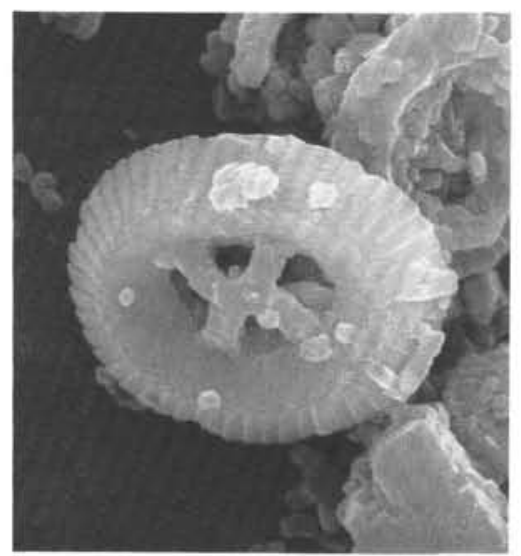

4

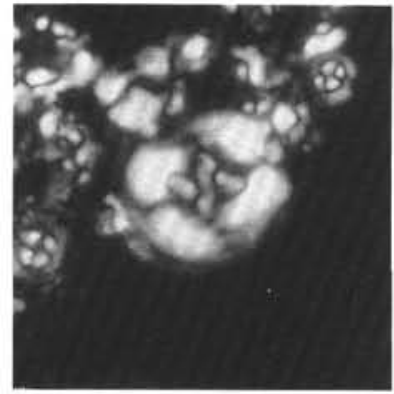

7

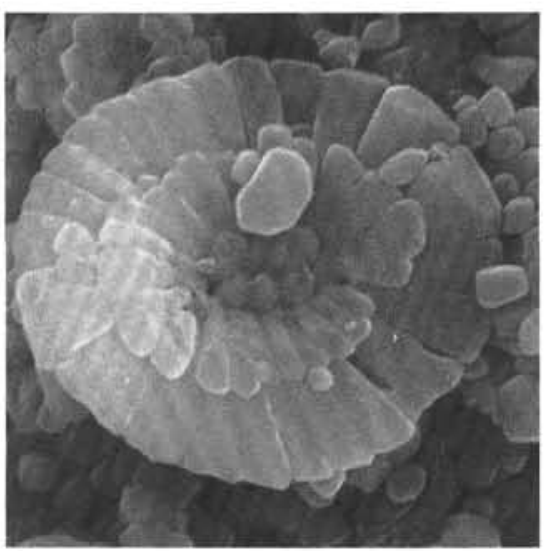

2

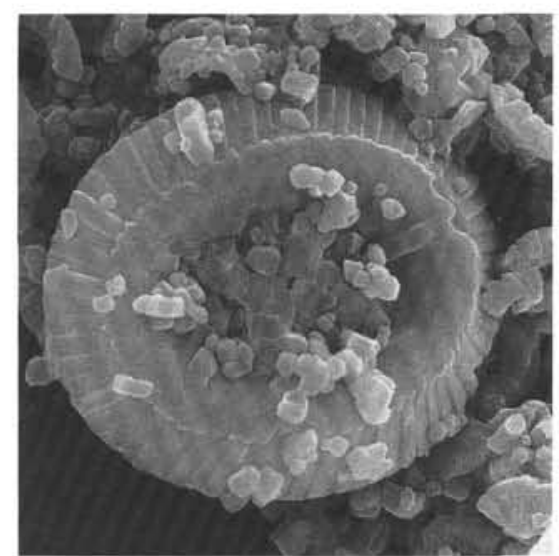

3

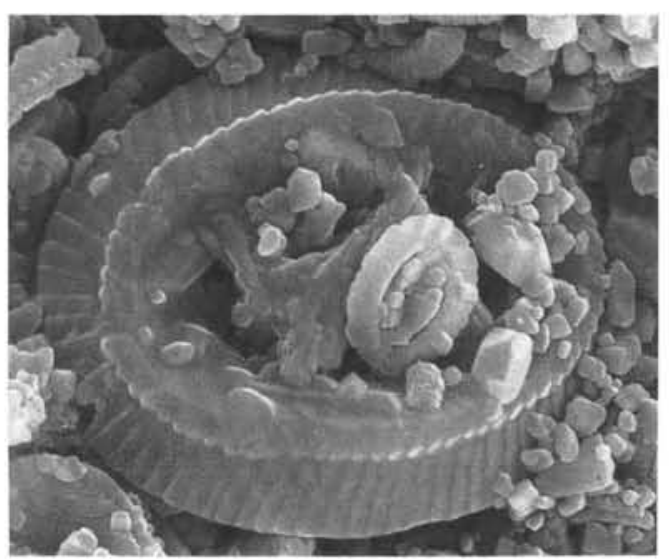

5

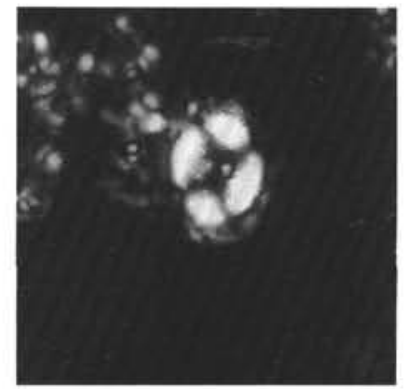

8

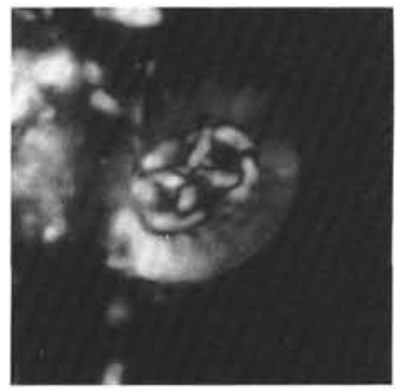

9

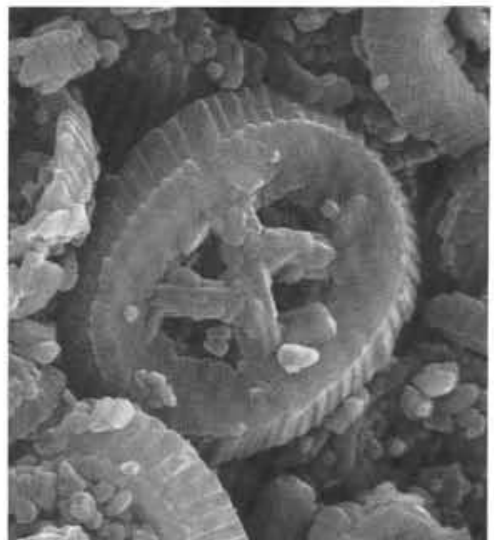

6

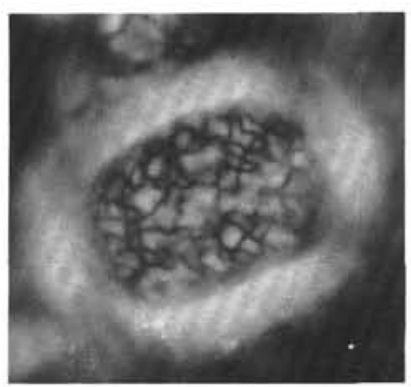

10

Plate 4. 1. Toweius pertusus (Sullivan) Romein, distal view, Sample 119-738C-17R-CC, 9,500×. 2. Markalius inversus (Deflandre) Bramlette and Martini, proximal view, Sample 119-738C-18R-7, 35-36 cm, 9,500×. 3, 4, 7. Chiasmolithus danicus (Brotzen) Hay and Mohler. (3) distal view, Sample 119-738C-18R-CC, 4,000 × (4) distal view, Sample 119-738C-19R-1, 35-36 cm, 5,000 × (7) Sample 119-738C-19R-1, 85-86 cm, 2,500 $\times$. 5, 6. Chiasmolithus bidens (Bramlette and Sullivan) Hay and Mohler, distal view, Sample 119-738C-17R-CC, 4,500 $\times$. 8. Coccolithus pelagicus (Willich) Schiller, Sample 119-738C-19R-2, 135-136 cm, 2,500×. 9. Prediscosphaera cretacea (Arkhangelsky) Gartner, Sample 119-738C-20R-4, $117-118 \mathrm{~cm}, 2,500 \times$. 10. Cribrosphaerella daniae Perch-Nielsen, Sample 119-738C-20R-5, $35 \mathrm{~cm}, 2,500 \times$. 